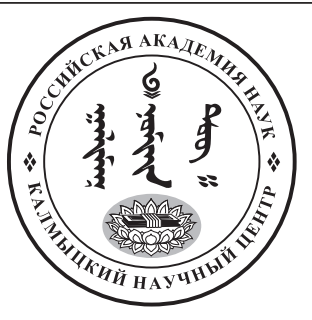

Published in the Russian Federation

Oriental Studies (Previous Name: Bulletin of the Kalmyk Institute

for Humanities of the Russian Academy of Sciences)

Has been issued as a journal since 2008

ISSN: 2619-0990; E-ISSN: 2619-1008

Vol. 13, Is. 5, pp. 1184-1217, 2020

DOI: $10.22162 / 2619-0990-2020-51-5-1184-1217$

Journal homepage: https://kigiran.elpub.ru

УДК 623.445.2; 903.22

DOI 10.22162/2619-0990-2020-51-5-1184-1217

\title{
«Шапка колмыцкая болшая» из собрания Музеев Московского Кремля
}

\author{
Леонид Александрович Бобров ${ }^{1}$, Сергей Павлович Орленко
}

${ }^{1}$ Новосибирский государственный университет (д. 1, ул. Пирогова, 630090 Новосибирск, Российская Федерация)

доктор исторических наук, доцент, ведущий научный сотрудник

iD 0000-0001-5071-1116. E-mail: spsml@mail.ru

${ }^{2}$ Музеи Московского Кремля (Кремль, 103132 Москва, Российская Федерация) кандидат исторических наук, ведущий научный сотрудник

iD 0000-0002-1219-8400. E-mail: orlenko@kremlin.museum.ru

\author{
(C) КалмНЦ РАН, 2020 \\ (C) Бобров Л. А., Орленко С. П., 2020
}

Аннотация. Введение. В статье рассмотрен шлем, хранящийся в фондах Музеев Московского Кремля, упомянутый в документах Оружейной Палаты последней четверти XVII в. как «Шапка колмыцкая болшая» (современный инвентарный номер: ОР-2059). Ранее наголовье уже привлекало внимание художников и историков, однако ни разу не становилось объектом отдельного научного исследования. Цель исследования — дать описание конструкции и оформления шлема, уточнить датировку и атрибуцию, реконструировать возможный первоначальный вид наголовья. Результаты. По материалу изготовления шлем относится к классу железных, по конструкции тульи - к отделу клепанных, по форме купола — к типу сфероцилиндрических. Установлено, что шлем входит в состав группы ойратских сфероцилиндрических («кувшинообразных», «вазообразных») наголовий позднего Средневековья и раннего Нового времени. Весьма вероятно, что мастера, изготовлявшие данные шлемы, вдохновлялись образом буддийской ступы. Особенности конструкции, оформления (в том числе наличие на тулье шлема буддийской символики), а также анализ служебной документации Оружейной Палаты позволяют предположить, что «Шапка колмыцкая болшая» была выкована ойратскими или южносибирскими оружейниками для состоятельного ойратского воина-буддиста в 1610-х - начале 1680-х гг. (нижняя граница возможной даты изготовления обусловлена началом широкого распространения буддизма среди ойратов). Шлем была передан в Оружейную Палату в середине - второй половине XVII в., но не позднее 1682 г., когда он впервые упоминается в русской служебной документации. В 1683-1687 гг. наголовье было снабжено подшлемником и бармицей 
(предположительно центральноазиатского образца). Впоследствии шлем становился объектом реставрационных работ. Не ранее конца XIX - начала XX в. к нему была подвешена кольчатая бармица. Комплексный анализ источников позволил реконструировать возможный первоначальный вид изучаемого шлема. Bblвoдbl. «Шапка колмыцкая болшая» представляет собой яркий образец ойратских шлемов XVII в. Она может использоваться в качестве эталона при датировке и атрибуции шлемов населения Центральной Азии указанного периода. В культурном плане «Шапка колмыцкая болшая» может быть отнесена к одной из важных исторических реликвий калмыцкого народа.

Ключевые слова: ойраты, калмыки, джунгары, ойратские шлемы, калмыцкие шлемы, «шапки калмыцкие»

Благодарность. Исследование проведено в рамках государственного задания Минобрнауки в сфере научной деятельности (проект № FSUS-2020-0021).

Для цитирования: Бобров Л. А., Орленко С. П. «Шапка колмыцкая болшая» из собрания Музеев Московского Кремля // Oriental Studies. 2020. Т. 13. № 5. С. 1184-1217. DOI: 10.22162/2619-0990-2020-51-5-1184-1217

UDC 623.445.2; 903.22

DOI 10.22162/2619-0990-2020-51-5-1184-1217

\title{
'Kalmyk Shapka Bolshaya': An Oirat Helmet from the Moscow Kremlin Museums Collection
}

\section{Leonid A. Bobrov ${ }^{1}$, Sergei P. Orlenko ${ }^{2}$}

${ }^{1}$ Novosibirsk State University (1, Pirogov St., Novosibirsk 630090, Russian Federation)

Dr. Sc. (History), Leading Research Associate, Associate Professor

iD 0000-0001-5071-1116. E-mail: spsml@mail.ru

${ }^{2}$ Moscow Kremlin Museums (Kremlin, Moscow 103132, Russian Federation)

Cand. Sc. (History), Leading Research Associate

iD 0000-0002-1219-8400. E-mail: orlenko@kremlin.museum.ru

(C) KalmSC RAS, 2020

(C) Bobrov L. A., Orlenko S. P., 2020

\begin{abstract}
Introduction. The article explores a helmet of the last quarter of the $17^{\text {th }}$ century stored in the Moscow Kremlin Museums collection and mentioned in the Armory Chamber's documents as 'Kalmyk shapka bolshaya' (Russ. 'big Kalmyk cap'; current inventory no. OP-2059). Previously, the helmet attracted the attention of artists and historians but has never been investigated in an independent scholarly study. Goals. The work seeks to describe the construction and design of the helmet, clarify the dating and attribution, reconstruct its potential original appearance. Results. Analysis of the materials used classifies the helmet as an iron object, that of the design of the crown refers it to riveted ones, and the dome crown shape clusters the item with spherocylindrical helmets. The paper specifies that the helmet is integral to the Oirat spherocylindrical helmet group ('jug-shaped', 'vase-shaped') of the Late Middle Ages and early Modern Period. Supposedly, the craftsmen to have made such helmets were inspired by Buddhist stupas (Kalm. suburgan). The construction and design features (including Buddhist symbols on the crown), as well as the insight into official documents of the Kremlin Armory make it possible to suggest that the 'Big Kalmyk Cap' was forged by Oirat or Southern Siberian gunsmiths for a wealthy Oirat Buddhist warrior in the 1610s - early 1680s (the earlier date is included as one to mark the beginning of the wide spread of Buddhism among Oirats). The helmet was transferred to the Armory Chamber in the mid-to-late $17^{\text {th }}$ century, however no later than 1682 when it was first mentioned in official Russian state papers. In 1683-1687, the helmet was
\end{abstract}


equipped with a comforter and an aventail (presumably a Central Asian-type one). Subsequently, it became a subject of restoration. In the late $19^{\text {th }}-$ early $20^{\text {th }}$ century at the earliest, a ringed aventail was attached to it. The comprehensive analysis of the sources available made it possible to reconstruct the likely initial appearance of the helmet. Conclusions. The 'Big Kalmyk Cap' is a striking sample of $17^{\text {th }}$-century Oirat helmets. It can be used as a reference benchmark in the dating and attribution of Central Asian helmets of the specified period. Culturally, the 'Big Kalmyk Cap' can be clustered with the most important historical relics of the ethnos.

Keywords: Oirats, Kalmyks, Dzungars, Oirat helmets, Kalmyk helmets, Kalmyk shapkas

Acknowledgements. The reported study was funded by state assignment (Ministry of Science and Higher Education of Russia), project no. FSUS-2020-0021.

For citation: Bobrov L. A., Orlenko S. P. 'Kalmyk Shapka Bolshaya': An Oirat Helmet from the Moscow Kremlin Museums Collection. Oriental Studies. 2020. Vol. 13(5): 1184-1217. (In Russ.). DOI: 10.22162/2619-0990-2020-51-5-1184-1217

\section{Введение}

Одной из важных причин успешных военных кампаний джунгар, волжских и «чакарских» калмыков, хошутов Кукунора против их противников в Центральной Азии, Южной Сибири и Восточной Европе в XVII в. было наличие в ойратских войсках достаточно многочисленных контингентов панцирной («куяшной») конницы, способной эффективно сражаться как в дистанционном, так и ближнем бою [Бобров, Худяков 2008: 353-366; 567-600; Бобров 2014: 243247; Бобров, Рюмшин 2015: 370-374]. В настоящее время образцы ойратского защитного вооружения (корпусные панцири, шлемы, мисюрки, наручи, дополнительные защитные детали и др.) хранятся во многих российских и иностранных музейных и частных собраниях. Выявление, систематизация и всесторонний анализ этих предметов представляет собой актуальную научную задачу. Особую ценность в данной связи имеют шлемы ойратского и южносибирского производства, хранящиеся в фондах Оружейной Палаты Московского Кремля ${ }^{1}$, названные царскими чиновниками «шапка-

${ }^{1}$ В настоящее время Оружейная Палата организационно входит в состав Государственного историко-культурного музея-заповедника «Московский Кремль», государственного музейного учреждения «Музеи Московского Кремля» (далее - ММК). ми калмыцкими» [Опись 1884: 35-39, 54]². Их высокая научная ценность обусловлена не только хорошей сохранностью, но и тем фактом, что в русской служебной документации XVII в. часто содержатся сведения о времени поступления и (или) начальных этапах хранения указанных наголовий в различных учреждениях Российского государства [Бобров, Орленко 2017: 128, 134]. Таким образом, «шапки калмыцкие» из собрания Оружейной Палаты представляют собой своеобразный эталон при датировке и атрибуции ойратских шлемов, происходящих из числа случайных находок и обнаруженных в ходе археологических раскопок в Поволжье, Сибири и Центральной Азии позднего Средневековья и раннего Нового времени [Бобров, Орленко 2017: 128, 134].

Среди серии «шапок калмыцких» в собрании ММК выделяется высокий и комплектный сфероцилиндрический шлем (инв. номер ОР-2059), обозначенный в материалах проверки Большой Государевой

${ }^{2}$ В русском языке середины XVI-XVII вв. термин «шапка» в сфере защитного вооружения имел два основных значения. В узком смысле под ним понимали низкие шлемы преимущественно сфероконической и полусферической формы. В широком значении термин «шапка» мог использоваться как синоним боевого наголовья вообще [Ленц 1895: 44; Историческое описание... 2008: 29; Шиндлер 2016: 177-181; Шиндлер 2018: 167-169, 171-173, 178]. 




Puc. 1. «Шапка колмыцкая болшая». 10-е - начало 80-х гг. XVII в. (до 1682 г.). Железо: ковка, гравировка, канфарение, клепка. Музеи Московского Кремля (инв. номер: ОР-2059). Фото С. В. Баранова

[Fig. 1. "Big Kalmyk shapka". Oiratia or South Siberia, 10th - early 80s. XVII century (until 1682). Iron: forging, engraving, riveting. Moscow Kremlin Museums, OR-2059. Photo by S. V. Baranov] 
Казны 1682 г. как «Шапка колмыцкая болшая» (рис. 1). Несмотря на то, что изображения и краткие описания наголовья уже публиковались в отечественных и зарубежных изданиях, о чем сказано ниже, оно еще ни разу становилось объектом отдельного научного исследования. Целью настоящей статьи является детальное описание конструкции и системы оформления шлема ОР-2059, уточнение его датировки и атрибуции, а также реконструкция возможного первоначального внешнего вида наголовья.

\section{Материалы и методы}

Методологическим основанием исследований по изучению защитного вооружения (в том числе боевых наголовий) народов Евразии эпохи Средневековья и раннего Нового времени являются принципы историзма, объективности, а также системный подход. Последний состоит в целостном рассмотрении совокупности объектов, при котором выясняется, что их взаимосвязь приводит к появлению новых интегративных свойств системы. В рамках применения системного подхода к изучаемому материалу отдельные предметы и комплексы защитного вооружения изучаются как обособленное и развивающееся целое, состоящее из согласованных, необходимых и достаточных для существования данной системы элементов, каждый из которых обладает способностью к самостоятельному развитию при сохранении целостных характеристик системы. В рамках системного подхода используются рациональные положения эволюционизма (изменчивость и наследственность) и диффузионизма (заимствование, перенос, смешение).

Методика обработки источников определяется задачами исследования. На этапах анализа и интерпретации материалов в оружиеведческих работах, посвященных изучению боевых наголовий, традиционно применяются классификационный, морфологический, типологический, сравнительно-описательный методы, метод датированных аналогий, верификации и корреляции полученных результатов. На этапах художественной и предметной научноисторической реконструкции возможного первоначального вида шлема используется комплексный подход, основанный на сопоставлении вещественных, письменных и изобразительных источников [Bobrov, Obraztsov, Salnikov 2019: 7, 8].

\section{Основная часть}

Рассмотрим историю изучения шлема OP-2059, особенности его конструкции и системы декоративного оформления, а также вопросы датировки и атрибуции.

История изучения "Шапки колмыцкой болшой» (ОР-2059)

Вероятно, самым ранним цветным изображением интересующего нас наголовья является рисунок выдающегося российского художника, академика исторической живописи Ф. Г. Солнцева (1801-1892). Он был подготовлен еще в первой половине XIX в. для публикации в фундаментальном издании «Древности Российского Государства» [Древности 1853 [Альбом]: рис. 27]. Шлем изображен в четырех проекциях: вид спереди, слева, сверху и снизу [Броня 2015: 31; Бобров, Орленко 2020: 282]. Необходимо отметить, что цветной рисунок исполнен весьма тщательно, с соблюдением основных пропорций и конструктивных элементов наголовья. Среди деталей, в силу различных причин не зафиксированных художником, следует упомянуть вырезы на боковых лопастях «щитка» козырька, гравированные рисунки и орнаменты на тулье и обруче «шапки калмыцкой» и др. Кроме того, не совсем точно передана форма бутонообразных насадок на подвершии шлема. В то же время, несмотря на указанные недочеты, рисунок Ф. Г. Солнцева на протяжении длительного времени оставался наиболее подробным и точным изображением рассматриваемого наголовья.

Необычная сфероцилиндрическая форма тульи «Шапки колмыцкой болшой», увенчанная высоким ярусным навершием, привлекла внимание и другого российского исследователя XIX в. - А. Ф. Вельтмана (1800-1870). При подготовке книги «Московская Оружейная палата», изданной в 1844 г., он посчитал необходимым изобразить на одной из ее иллюстраций и интересующее нас наголовье [Вельтман 1844: после с. 82; Бобров, Орленко 2020: 284]. Однако стремление разместить на одном рисунке как можно больше образцов защитного вооружения привело к тому, что художник поместил сфероцилиндрический шлем лишь в третий ряд изображаемых предметов. 
В результате зритель может видеть лишь верхнюю часть тульи «шапки колмыцкой» c круглым подвершием, бутонообразными насадками и трубкой-втулкой для плюмажа [Вельтман 1844: после с. 82; Бобров, Орленко 2020: 284]. При этом некоторые пропорции и детали изображения были искажены художником. Во второе издание «Московской Оружейной палаты» данный рисунок уже не вошел [Вельтман 1860: 214].

Во второй половине XIX в. Л. П. Яковлев систематизировал документы Оружейной Палаты и предложил свою атрибуцию рассматриваемого в настоящей статье наголовья. Он датировал его XVI в. и определил как «шапку калмыцкую»: «4419³. ШАПКА КАЛМЫЦКАЯ XVI ВЕКА. Железная; колпак состоит из восьми выгнутых железных пластинок, скрепленных гвоздями; навершье плоское, круглое, край, загнутый тремя городками, прикреплен к колпаку четырьмя барашками; подвершья - толстая железная, высокая трубка, к верху восьмигранная и с раструбом; по длине трубки шесть поясков, венец плоский, гладкий, прикреплен к колпаку железными гвоздями, по венцу было канфарено; на нем десять скважин, для прикрепления затылка, наушей и бармицы, которых нет; полка гладкая, коробчатая, весу 2 фун<та > 85 золотников...» [Опись 1884: 36]. По мнению Л. П. Яковлева, указанная «шапка калмыцкая», а также другой сфероцилиндрический шлем из собрания Оружейной Палаты (инв. номер ОР-4645) были близки шлемам воинов Цинской империи XIX в.: «Эти шапки, названныя, согласно со старыми описями, Калмыцкими, близко подходят видом и очертанием своим к шапкам китайскаго войска новейшаго времени» [Опись 1884: 37]. Текст Л. П. Яковлева был проиллюстрирован черно-белой фотографией «большого» шлема (ОР-2059) в анфас, отпечатанной в технике фототипии (для определения размеров в кадре присутствует масштабная линейка). Компанию «шапке колмыцкой» на фотографии составили два русских цельнокованых «шелома» [Рисунки 1884: табл. 343].

Спустя почти столетие, в 1979 г., М. В. Горелик использовал шлем ОР-2059

34419 - инвентарный номер «Шапки колмыцкой болшой» в 1884 г. Современный инв. № OP-2059. из Оружейной палаты для реконструкции внешнего облика монгольского воина XVII в. Наголовья рассматриваемого образца он обозначил как шлемы «вычурной формы» [Горелик 1979: 97, рис. 4, 99].

В 2003 г. Л. А. Бобровым и Ю. С. Худяковым была опубликована статья, посвященная боевым наголовьям кочевников Монголии и Калмыкии второй половины XVI - начала XVIII вв. В числе прочих в статье были приведены прорисовки рассматриваемого шлема из собрания Оружейной Палаты (в двух проекциях), описаны особенности его конструкции и оформления, указаны основные размеры, а также введен и обоснован новый тип клепаных наголовий центральноазиатского образца - «сфероцилиндрические шлемы» [Бобров, Худяков 2003: 144, 145, 153, табл. 3, рис. 3] $]^{4}$. На основании типологического анализа наголовье было атрибутировано как монгольский (ойратский, джунгарский) шлем и датировано XVI-XVII вв. [Бобров, Худяков 2003: $145,155]$. Комплексный анализ источников позволил реконструировать возможный покрой и структуру бронирования бармицы, защищавшей уши и шею воина, а также особенности ношения и украшения шлемов подобного типа [Бобров, Худяков 2003: 154, табл. 4, рис. 1].

В монографии 2008 г. «Вооружение и тактика кочевников в Центральной Азии и Южной Сибири в эпоху позднего Средневековья и раннего Нового времени (XV - первая половина XVIII вв.)» Л. А. Бобров и Ю. С. Худяков вновь вернулись к изучению «Шапки колмыцкой болшой». Прежнее описание было расширено, a количество прорисовок проекций шлема увеличено до четырех. Наголовье было атрибутировано как ойратский сфероцилиндрический шлем и датировано концом XVI-XVII в. [Бобров, Худяков 2008: 443, 444, 461, рис. 191, 2]. Было установлено, что шлемы указанной конструкции не являлись редкой оружейной экзотикой, а имели определенное распространение среди ойратских воинов позднего Средневековья и раннего

4 Наряду с указанным термином, применяемым в рамках формально-типологической классификации, авторы предложили и другие (условные) названия рассматриваемого типа наголовий: «кувшинообразные», «вазообразные» шлемы [Бобров, Худяков 2003: 144, 145]. 
Нового времени [Бобров, Худяков 2008: 440-445, 459-461, 722, 725].

В 2006 г. американский исследователь Д. ЛаРокка использовал рисунок Ф. Г. Солнцева «Шапки колмыцкой болшой» для датировки сфероцилиндрического шлема из собрания музея искусств «Метрополитен» (г. Нью-Йорк, США). Ученый предположил, что изучаемое им наголовье происходит из Западного Тибета или Центральной Азии и может быть датировано XIV-XVI вв. [LaRocca 2006: 88, 89].

Таким образом, шлем ОР-2059 из собрания ММК неоднократно привлекал внимание российских и зарубежных исследователей. Однако цветные фотографии «Шапки колмыцкой болшой» ранее не публиковались. Кроме того, как было отмечено выше, данный шлем еще не становился объектом отдельного научного исследования, а изучался наряду с другими боевыми наголовьями кочевников Центральной Азии и Южной Сибири.

«Шапка калмыцкая болшая" в собрании Оружейной Палаты Московского Кремля

К сожалению, достоверно установить обстоятельства и время поступления интересующего нас наголовья в Оружейную Палату на основании имеющихся письменных источников в настоящее время не представляется возможным. Однако данный артефакт уже находился в собрании на момент проверки Большой Государевой Казны в 1682 г. Наиболее вероятно, что шлем поступил в царское хранилище в середине XVII в. вместе с другими «шапками калмыцкими», присланными из Центральной Азии и Сибири [Бобров, Орленко 2020: 286-293].

Описи Оружейной Палаты последней четверти XVII-XIX вв. позволяют проследить состояние и комплектность изучаемого сфероцилиндрического шлема на протяжении указанного периода.

Рассматриваемый шлем особо отмечен при проверке Большой Государевой Казны в 1682 г. В Переписной книге 1687 г. он упомянут в главе «Шапки Немецкие и Калмыцкие» под № 6 и описан следующим образом: «Шапка колмыцкая болшая, с трубкою, доски сшиваны гвоздьем ${ }^{5}$, по венцу

5 То есть пластины тульи шлема («доски») соединены заклепками («гвоздями»). канфарено ${ }^{6}$, полка гладкая 7 . Невооружена»; «А по нонешней переписи 195 (1687) году и по осмотру та шапка против прежних переписных книг (1682 года. - Aвm.) сошлась, а по осмотру та шапка вооружена. Цена полтина» [Опись 1884: 36]. Данные сведения указывают на то, что в 1682 г. наголовье не имело подшлемника и бармицы (то есть была «невооружена»), которые были добавлены к шлему не позднее 1687 г. Описание «Шапки колмыцкой болшой», сделанное в 1682 г., стало базовым для реестров Оружейной Палаты следующего столетия. Со временем описание конструкции наголовья в служебной документации становилось более лаконичным, но, тем не менее, хорошо узнаваемым.

В описи 1701 г. шлем упомянут в главе «Шапки Немецкие и Колмыцкие» под № 6: «Шапка калмыцкая большая с трубкой. Доски сшиваны гвоздьем. По венцу канфарено. Полка глаткая. Невооружена ${ }^{8}$. Цена полтина» [РГАДА. Ф. 396. Оп. 2. Д. 937. Опись ОП 1701 г. Л. 233].

${ }^{6}$ Канфарение - украшение поверхности металлического предмета равномерно расположенными мелкими точками, штрихами, линиями и т. д. с помощью особых чеканов или пуассонов. В рассматриваемом случае фон гравированного рисунка на обруче («венце») шлема украшен канфарением в виде множества точек.

7 Термин «полка», в данном случае, использован, как синоним слова «козырек». При более подробном описании подобных «коробчатых» (объемных) козырьков могли выделяться его два основных конструктивных элемента — «полка» и «щиток».

8 Здесь, возможно, авторами описи была допущена ошибка (автоматически повторенная в реестре 1711 г.), так как в описи 1727 г. упоминается, что указанный шлем, к этому времени, лишился «одного наушня и подкладки кумашной» (см. ниже), то есть в этот период «вооружение» наголовья (пусть и частично), было еще в наличии. Не исключено, что фразу «Невооружена» в описях 1701 и 1711 гг. следует понимать, как неполное оснащение (т. е. отсутствие некоторых органических и металлических элементов) шлема, которое и было более подробно зафиксировано в 1727 г. В противном случае придется предположить, что «вооружение» шапки, отмеченное в 1687 г. исчезло к 1701 г., а затем было частично добавлено (восстановлено?) между 1711-1726 гг. Однако последняя версия, представляется все же маловероятной. 
В описи 1711 г. описание наголовья помещено в главу ««Шапки немецкие и калмыцкие» под № 18: «Шапка калмыцкая большая с трубкою. Доски сшиваны гвоздьем. По венцу канфарено. Полка глаткая. Невооружена. Цена 16 алтын 4 деньги. А по нынешнему осмотру сходно» [РГАДА. Ф. 396. Оп. 2. Д. 939. Опись ОП 1711 г. Л. 306, 306об.].
В описи 1727 г. наголовье записано уже среди «Шапок ерихонских» под тем же № 18 с отметкой: «...одного наушня и подкладки кумашной нет» [РГАДА. Ф. 396. Оп. 2. Д. 1243. Опись ОП 1727 г. Л. 681об.]. Сами данные описи 1727 г. представлены в виде таблицы. В левом столбце приведены сведения 1711 г., а в правом - результаты осмотра шлема:

\begin{tabular}{|c|c|}
\hline Опись & Осмотр \\
\hline $\begin{array}{l}18 \\
\text { Шапка калмыцкая большая с трубкою Доски сшиваны } \\
\text { гвоздьем. По венцу канфарено. Полка глаткая. Невооружена. } \\
\text { Цена шеснатцать алтын четыре деньги. А по нынешнему } \\
\text { осмотру сходно. }\end{array}$ & $\begin{array}{l}\text { Есть [в наличии] } \\
\text { А ныне по осмотру одного наушня } \\
\text { и подкладки кумашной нет. }\end{array}$ \\
\hline
\end{tabular}

В описи 1746 г., также составленной в виде таблицы, рассматриваемый шлем включен в главу «Шапки Ерихонские» под № 18 в числе прочих наголовий со специальной отметкой «погорели» [РГАДА. Ф. 396. Оп. 2. Д. 1252. Опись ОП 1746 г. Л. 385].

\begin{tabular}{|c|c|}
\hline 18 & [Погоре]ли \\
Шапка калмыцкая большая с трубкою. Доски сшиваны & \\
гвоздьем. По венцу канфарено. Полка глаткая. Невооружена. & \\
Бес подкладки. У ней один наушник. Цена пятьдесят копеек. & \\
\hline
\end{tabular}

Это указывает на то, что шлем в числе прочих «шапок калмыцких» стал жертвой знаменитого пожара 1737 г. По мнению Л. П. Яковлева, именно в этот момент «шапки калмыцкие» лишились своих органических элементов: «В настоящее время наушников и бархата нет; их уничтожил пожар 1737 года; в котором эти шишаки обгорели; невозможность отчистить нагар и желание предохранить от ржавчины, вероятно, были причиною того, что некоторые из шишаков, окрашены черною масляною краскою; когда произведена эта окраска, из дел Архива не видно» [Опись 1884: $38,39]$.

${ }^{9}$ На листах с описаниями шапок калмыцких с листа 384об. в правом столбце проставлено по слогам: «/По / го/ pe/ ли/» [РГАДА. Ф. 396. Оп. 2. Д. 1252. Опись ОП 1746 г. Л. 384об.]. Кроме того, на следующем листе «385» поверх оригинальной рукописи 1746 г. карандашом проставлен номер шлема «5587», под которым наголовье вошло в опись 1835 г. [РГАДА. Ф. 396. Оп. 2. Д. 1252. Опись ОП 1746 г. Л. 385].
В описи 1780 г. ${ }^{10}$ исследуемый шлем указан в главе «Шапки», в разделе «Калмыцкие» под двумя номерами: № 150 и № 14. Подобная нумерация обусловлена спецификой документа, оформленного в виде таблицы из нескольких столбцов. В первом столбце указывался общий порядковый номер предмета ${ }^{11}$. Во втором номер предмета в данной главе. В третьем - номер листа в описи 1746 г. Наконец, в четвертом столбце помещалось крайне лаконичное описание шлема [РГАДА. Ф. 396. Оп. 2. Д. 1255. Опись ОП 1780 г. Л. 23].

10 Л. П. Яковлев или (более вероятно) издатели описи Оружейной Палаты 1884 г. ошибочно датировали этот документ 1773 г. [Опись 1884: 36]. При описании других вещей этот же реестр на соседних страницах издания 1884 г. датируется уже 1775 г. [Опись 1884: 37]. То есть датировка упомянутой описи 1773 годом в издании 1884 г. является явной опечаткой.

${ }^{11}$ Нумерация шлемов в описи 1783 г. начинается не с главы «Шапки», как это было в более ранних реестрах XVIII в., а с предшествующей главы «Шишаки». 




Puc. 2. «Шапка колмыцкая болшая». Вид спереди. Фото С. В. Баранова

[Fig. 2. "Big Kalmyk shapka". Front view. Photo by S. V. Baranov] 


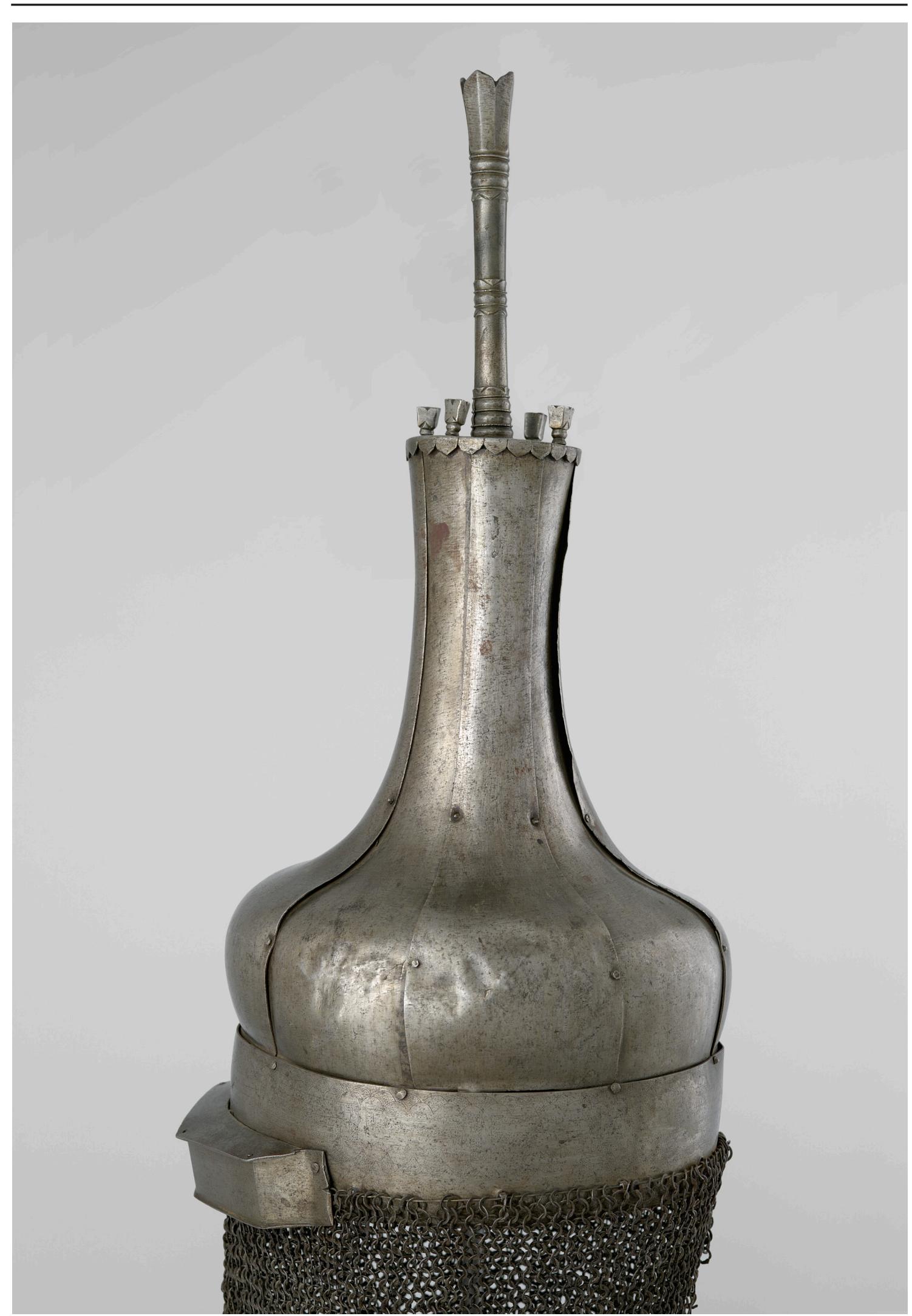

Puc. 3. «Шапка колмыцкая болшая». Вид слева. Фото С. В. Баранова

[Fig. 3. "Big Kalmyk shapka”. Left view. Photo by S. V. Baranov] 


\begin{tabular}{|l|l|l|l|}
\hline 1150 & 114 & 385 & Большая с трубкою. Доски обиты гвоздьми. 50 коп. \\
\hline
\end{tabular}

В описи 1808-1810 гг. ${ }^{12}$ шлем упомянут под № 6518 и впервые описан достаточно подробно: «Шапка стальная, имеющая вид церковной главы, состоящая из восьми выгнутых дощечек, скрепленная изредка стальными ж гвоздиками. По низу соединены стальным ободом с порезкою ${ }^{13}$, к коему прикреплен пятиугольный щиток или козырек. А на верхнем конце наложена стальная коробка с вырезанными городами краями ${ }^{14}$. На средине ее высокая трубка, прикрепленная посредством четырех винтов» [РГИА. Ф. 468. Оп. 1. Д. 4009 (Опись вещам Мастерской и Оружейной палаты 1808 г.). Л. 489об.-490].

В описи 1835 г. шлем упомянут под № 5587. Описание в целом повторяет реестр 1808 г., но с некоторыми описками и уточнениями. К числу последних можно отнести переименование подвершия шлема из «коробки» в «крышку»: «Шишак стальной, сделанный на подобии церковной клавы $^{15}$, состоящий из осьми выгнутых дощечек, склепанных стальными гвоздиками. По низу сии соединены стальным с порезкою ободом, к коему прикреплен пятиугольный щиток. На верху же наложена стальная с вырезанными городами краем крышка. На средине коей находится прикрепленная к доскам посредством четырех винтов высокая трубка» [ОРГПФ ММК. Ф. 1 Оп. 1. Д. 6 (Опись вещам Московской Оружейной палаты, составленная в 1835-м году). Л. 631. № 5587].

Определенный интерес представляет описание шлема, представленное в описи 1861 г., в котором наголовье значится под № 3768. Составителем разделов, посвященных защитному вооружению (как и в последующей знаменитой описи 1884 г.) был упоминавшийся выше Л. П. Яковлев. В 1861 г.

12 Также известна как опись Оружейной палаты 1808 г.

13 Вероятно, имеется в виду гравированный узор на обруче шлема.

${ }^{14}$ Речь идет о подвершии шлема, стенки которого оформлены остроугольными фестонами, названными автором Описи 1808-1810 гг. «городами».

15 Так в тексте описи 1835 г. он не только подробно описал конструкцию наголовья, но и впервые попытался сопоставить сфероцилиндрические «шапки калмыцкие» с известными ему цинскими шлемами. Наличие исправлений (зачеркивание отдельных слов) рукописи показывает, что исследователь отказался от полного отождествления «шапок калмыцких» с дальневосточными аналогами, а также усомнился в первоначальной версии об использовании подобных шлемов в современных ему цинских кавалерийских подразделениях: «Колпак состоит из осьми вогнутых железных пластинок, скрепленных гвоздями; навершие плоское круглое, край, загнутый тремя городками, прикреплен к колпаку четырьмя барашками, головки которых зделаны в виде четырехугольных призмен (зачеркнуто. - Aвm.) трапецоидов; навершие толстая железная высока трубка поверху раструбом (зачеркнуто. - Aвm.) осьмигранным раструбом; по длине трубки шесть поясков; венец плоский гладкий, прикреплен к колпаку железными гвоздями, по венцу было канфарено; на нем десять скважин для прикрепления затылка, наушей и бармицы, которых нет; полка гладкая коробчатая; весу 2 ф. 85 з. ... Эти шапки названы согласно со старыми описями «Калмыцкими» - $\underline{\text { имеют }}$ совершенно (зачеркнуто. - $\mathrm{Aвm}$.) близко подходят видом и очертанием к шапкам которые употребляются (зачеркнуто. - Aвт.) Китайской кавалерией» [ОРГПФ ММК. Ф. 1. Оп. 1. Д. 16 Опись Оружейной палаты (знамена и оборонительное оружие). Ч. 3 гл. II (Шлемы, шишаки...) Составитель Л. Яковлев. Л. 98об., 100об.]. Как мы уже видели выше, в дальнейшем, при работе над текстом описи 1884 г., Л. П. Яковлев, хотя и не отказался от указания на типологическую близость сфероцилиндрических «шапок калмыцких» с «шапками китайского войска новейшаго времени», но высказал эту позицию уже более осторожно [Опись 1884: 37].

Таким образом, на протяжении последней четверти XVII-XIX вв. рассматриваемое сфероцилиндрическое наголовье дополнялось различными конструктивными элементами (пластинчато-нашивной или 
стеганой бармицей, состоявшей из «наушней» и, возможно, назатыльника, а также «подкладкой кумашной», т. е. подшлемником), становилось объектом реставрационных работ (часть заклепок на тулье заменена). Однако проведенный осмотр, а также сопоставление шлема с его описаниями XVII-XIX вв. и изображениями XIX в. показали, что интересующая нас «шапка колмыцкая» сохранила оригинальные пластины тульи и основные конструктивные элементы, присутствовавшие в ее первоначальной комплектации, что позволяет провести всесторонний типологический анализ шлема.

Описание конструкции и системы оформления «Шапки колмыцкой болшой» (ОР-2059, старый инвентарный номер 4419)

По материалу изготовления шлем относится к классу железных, по конструкции тульи - к отделу клепанных, по форме купола - к типу сфероцилиндрических. Общая высота наголовья 49,5 см. Высота полусферической части тульи около $16 \mathrm{~cm}$, примерно ту же высоту имеет и цилиндрическая часть купола шлема. Диаметр лобно-затылочный 21,5 см, височный 22 см. Толщина пластин тульи 0,6-0,8 мм, толщина обруча 1,4-1,6 мм. Вес шлема (без кольчатой бармицы) составляет 1,18 кг (рис. 2-5).

Тулья шлема склепана из восьми $\mathrm{S}$-образных в сечении пластин-секторов четырех основных и четырех накладок, которые по своим размерам практически не уступают основным пластинам (ширина у обруча около 8,5 см, у подвершия около 3,5 см). Накладки имеют удлиненно-трапециевидную, а основные пластины-сектоpa - удлиненно-подтреугольную форму. Их заостренные, снабженные отверстиями, лопасти изогнуты почти под прямым углом и служат в качестве подложки-основания крышкообразного подвершия наголовья (рис. 6). Благодаря подобному технологическому приему, а также S-образному сечению пластин тульи шлем в собранном виде приобретает ярко выраженный сфероцилиндрический силуэт (рис. 2-5) ${ }^{16}$. Каждая

${ }^{16} \mathrm{~S}$-образный изгиб пластин купола настолько силен, что диаметр полусферической части тульи наголовья визуально превышает диаметр обруча шлема. пластина-накладка незначительно перекрывает края двух соседних пластин и соединяется с ними при помощи двух пар железных заклепок (рис. 2-6).

На поверхности тульи зафиксированы механические повреждения в виде пробоин, проломов и вмятин, приведших к деформации пластин купола наголовья. Особенно сильно пострадала затылочная часть тульи (рис. 4, 5). Некоторые повреждения могут быть предварительно атрибутированы как следы дробящих ударов.

Осмотр тульи показал, что поверхность шлема была украшена различными изображениями, выполненными в технике гравировки и канфарения. Так, в частности, на налобную пластину нанесен рисунок, к сожалению, сильно затертый и трудно различимый (рис. 7) ${ }^{17}$. Его детальное изучение помогло восстановить указанное изображение (рис. 8) и атрибутировать его как одну из традиционных форм символического изображения Триратны (тиб. dkon mchog gsum) - Tрех драгоценностей буддийской доктрины: Будды, Дхармы и Сангхи [Бобров, Худяков 2008: 440, 441; Bobrov et al. 2017: 1159]. В месте перехода тульи шлема из полусферической в цилиндрическую пластины купола пересекает орнаментальная полоса, представляющая собой цепь гравированных ромбических фигур, внутреннее пространство которых заполнено канфарением в виде множества мелких точек (рис. 7, 8).

Дополнительным фиксатором пластин тульи является широкий составной железный обруч, опоясывающий шлем по его нижнему краю (ширина 5,4-6 см). Обруч склепан из двух частей: короткой (на правой затылочной части шлема) и длинной. Элементы обруча соединяются между собой с помощью трех железных заклепок с округлыми шляпками (рис. 4, 5). Основу узора на обруче шлема формирует популярный в Центральной Азии геометрический меандрообразный орнамент (монг. алхан xээ), нанесенный в технике гравировки. Фон рисунка заполнен канфарением (рис. 7, 8). Основное изображение обрамляют двойные ряды гравированных полукруглых фестонов, возможно представляющие собой сти-

${ }^{17}$ По данной причине он не был зафиксирован на рисунках шлема XIX - начала XXI вв. 


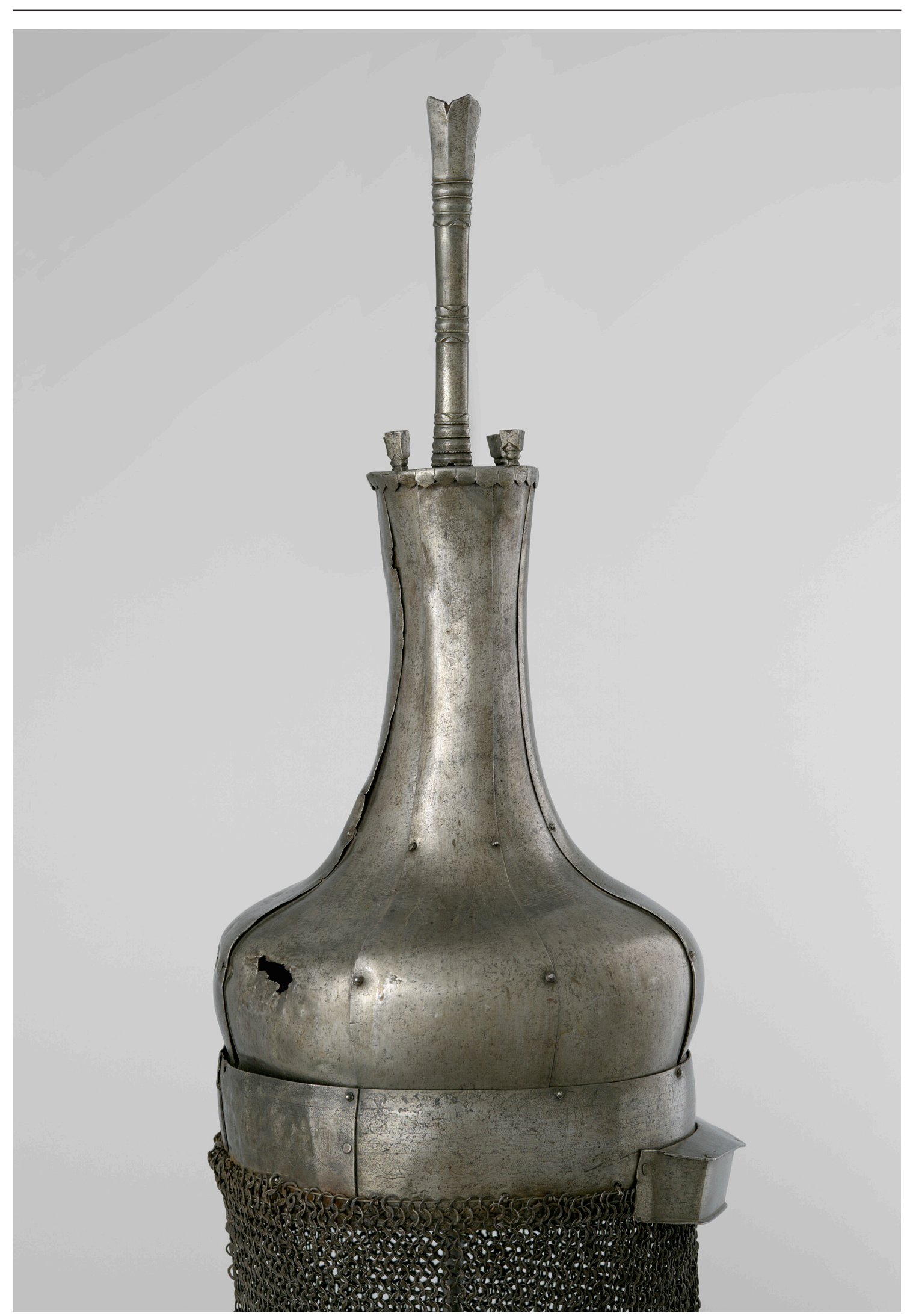

Рис. 4. ««Шапка колмыцкая болшая». Вид справа. Фото С. В. Баранова

[Fig. 4. "Big Kalmyk shapka". Right view. Photo by S. V. Baranov] 


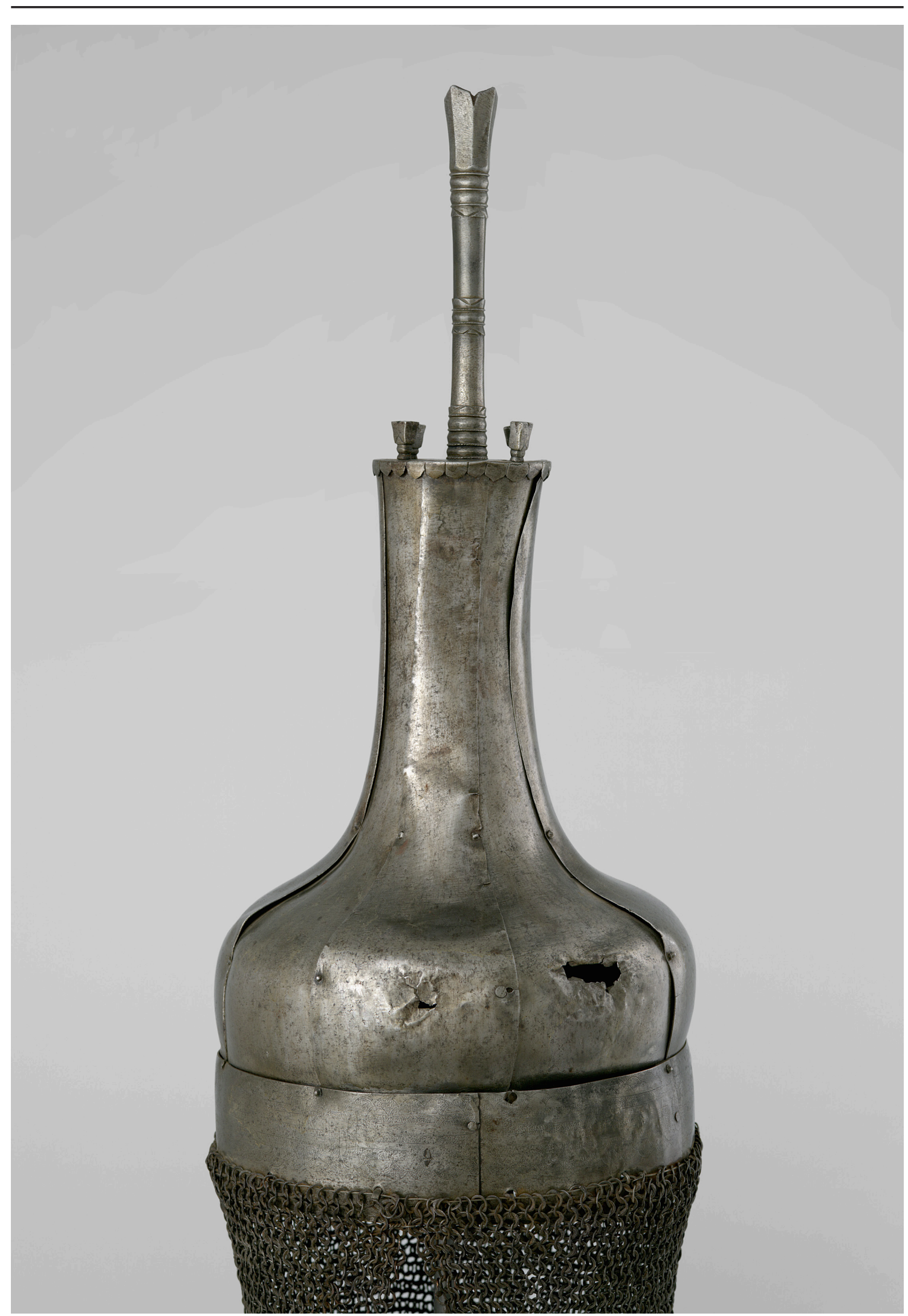

Puc. 5. ««Шапка колмыцкая болшая». Вид сзади. Фото С. В. Баранова

[Fig. 5. "Big Kalmyk shapka". Back view. Photo by S. V. Baranov] 
лизованное изображение лепестков лотоса (см. ниже). Ближние к центральному рисунку ряды фестонов гладкие, дальние проканфарены (покрыты точечным орнаментом).

К налобной части обруча прикреплен массивный «коробчатый» козырек, состоящий из горизонтальной пятиугольной «полки» и вертикального «щитка» с тремя ребрами жесткости (рис. 2-4, 7, 8). Козырек крепится к тулье с помощью железных заклепок, вбитых в боковые лопасти «щитка», которые украшены небольшими остроугольными вырезами. Длина козырька 22 см, ширина «полки» 2,7 см, ширина (высота) «щитка» по центру 3,2 см (рис. 2, 7). Вдоль нижнего края обруча пробиты десять сквозных отверстий, предназначенных для крепления бармицы (рис. 2-5).

Венчает шлем комбинированное навершие, состоящее из подвершия, трубки-втулки для плюмажа и четырех бутонообразных насадок (рис. 2-5, 9).

Подвершие (пластина-основание навершия) имеет «крышкообразную» форму. Высота подвершия 0,8-0,9 см, диаметр 8 см. Вертикальный железный бортик украшен остроугольными фестонами (рис. 2-5). По центру подвершия пробито сквозное отверстие, в которое вставлена трубка-втулка для плюмажа (высота 17,5 см, диаметр в нижней, центральной и верхней части - 1,9, 1,5, 1,9 см соответственно). Втулка украшена шестью уплощенными «яблоками» перемежающихся выпуклыми поясками, покрытыми мелкой насечкой. Три «яблока» расположены в основании втулки, одно - в центре и два - в ее верхней части. Пояски дополнены «манжетами», поверхность которых покрыта гравированными остроугольными фестонами (рис. 5). Восьмигранный раструб трубки (высота 2,5 см, диаметр 2,4 см) выполнен в виде распускающегося цветочного бутона, вероятно, символизирующего четырех- или восьмилепестковый лотос (тиб. pad ma) [Бир 2013: 28-30; Бобров, Зайцев, Орленко 2017: 220].

Наряду с втулкой в подвершие вставлены четыре бутонообразные насадки (высота 1,7-2,0 см), которые соединяют навершие с пластинами тульи шлема (рис. 9). Кроме сугубо функциональных задач, насадки несут и определенное символическое значение. Форма бутонов позволяет предположить, что они, как и плюмажная трубка, олицетворяют собой образы цветков лотоса [Бобров, Зайцев, Орленко 2017: 220].

В настоящее время в отверстия на обруче вставлены металлические петли, через которые пропущена железная проволока. К последней подвешена «глухая» бармица (длина около 54 см), снабженная остроугольной лопастью на лицевой стороне и разрезом на затылке (рис. 1-6). Полотно бармицы сплетено из уплощенных клепаных колец (диаметр 0,6-0,8 см). Необходимо отметить, что ни на рисунке Ф. Г. Солнцева, ни в материалах описей Оружейной палаты XVII-XIX вв. кольчатая бармица на рассматриваемой «шапке колмыцкой» не фиксируется. Нет ее и на фотографии шлема в приложении к книге «Опись Московской Оружейной палаты», опубликованной в 1884 г. [Рисунки 1884: табл. 343]. Однако она уже присутствовала на шлеме в начале 2000-х гг., когда наголовье было впервые осмотрено одним из авторов настоящей работы. Это позволяет предположить, что кольчатая бармица была подвешена к шлему в конце XIX-XX вв. Нет оснований полагать, что она могла входить в первоначальную комплектацию «Шапки колмыцкой болшой».

\section{Датировка и атрибуция}

Наголовье ОР-2059 из собрания ММК может быть датировано и атрибутировано на основании особенностей конструкции и системы оформления тульи и шлемовых элементов, а также служебной документации Оружейной Палаты XVII в.

Клепаные сфероцилиндрические («кувшинообразные», «вазообразные») шлемы с тульей из четырех основных пластин и четырех более или менее широких пластин-накладок являются достаточно популярной разновидностью боевых наголовий номадов Центральной Азии эпохи позднего Средневековья и раннего Нового времени. Для предшествующих исторических периодов подобные шлемы в целом нехарактерны [Gorelik 1979: 52-59; Горелик 1983: 262; Горелик 1987: 187-194; Горелик 2002: 7578; Бобров, Худяков 2003: 144; Ахметжан 2007: 153, рис. 131, 7; Бобров, Худяков 2008: 440-445, 459-461; Bobrov, Obraztsov, Salnikov 2019: 14]. 
Наряду с тульей важным датирующим признаком шлема является «коробчатый» козырек, состоящий изгоризонтальной «полки» и вертикального «щитка». Подобные козырьки представляют собой одну из основных форм защиты лица на боевых и парадных наголовьях состоятельных кочевников Центральной Азии XV-XVIII вв. [Бобров, Худяков 2003: 145; LaRocca 2006: 73-79, 88, 91; Бобров, Худяков 2008: 418, 426, 432, 440-444, 446, 447, 450-452; Анисимова 2013: 276, 277; Ахметжан 2007: 51, 53; Bobrov, Kushkumbayev, Salnikov 2018; Bobrov, Obraztsov, Salnikov 2019: 14].

Часто встречающимся элементом конструкции монгольских и ойратских шлемов позднего Средневековья и раннего Нового времени также являются железные трубки-втулки для плюмажа, украшенные шаровидными «яблоками» в обрамлении выпуклых поясков [LaRocca 2006: 73, 88, 89; Бобров, Худяков 2008: 418, 440, 441, 444, $445,460,461]$. Подобный тип держателя плюмажа является типичным для сфероцилиндрических шлемов указанного исторического периода [LaRocca 2006: 88, 89; Бобров, Худяков 2008: 440, 441, 444, 445, 460, 461; Bobrov, Obraztsov, Salnikov 2019: $14]$.

По совокупности признаков «Шапка колмыцкая болшая» из ММК может быть отнесена к особой группе шлемов, которая в настоящее время насчитывает 14 экземпляров, хранящихся в музейных и частных коллекциях России, Казахстана, Монголии, Китая, США и др. стран ${ }^{18}$. Отличительной особенностью данных наголовий является характерная сфероцилиндрическая тулья, склепанная из S-образных в сечении пластин-секторов. Стыки последних прикрыты широкими или (реже) узкими накладками с ровным краем. Практически обязательным элементом оформления является более или менее широкий обруч, а также «коробчатый» козырек. В тех случаях, когда шлем сохранил навершие, оно всегда состоит из плоского крышкообразного основания (подвершия), трубки-втулки для плюмажа и ряда дополнительных элементов (как пра-

${ }^{18}$ К данной группе примыкают еще четыре шлема, выполненные в подражание своим сфероцилиндрическим аналогам, но имеющие несколько иной силуэт, конструкцию и систему оформления. вило, стилизованных изображений бутонов восьмилепесткового лотоса). Все сфероцилиндрические шлемы данного типа соотносятся с комплексом вооружения ойратов конца XVI - середины XVIII вв. [Бобров, Худяков 2003: 144, 145; Бобров, Худяков 2008: 440-445, 459-461; Bobrov, Obraztsov, Salnikov 2019].

Ближайшим аналогом «Шапки колмыцкой болшой» из Оружейной Палаты является сфероцилиндрическое наголовье из собрания Тобольского государственного историко-архитектурного музея-заповедника (инв. № ВО-171, далее - ТГИАМЗ). Оно имеет не только практически идентичную конструкцию, но и близкие размеры и декоративное оформление [Бобров, Худяков 2008: 440, рис. 173: 441, рис. 174: 460 , рис. 190,2$]$. К налобной части шлема из ТГИАМЗ приклепан массивный двухчастный «коробчатый» козырек с тремя ребрами жесткости и характерными вырезами на боковых лопастях «щитка». Бортик крышкообразного подвершия, как и на подвершии шлема из ММК, оформлен остроугольными фестонами. Насадки на подвершии выкованы в виде цветочных бутонов. Рисунки на поверхности тульи и обруча выполнены в технике гравировки и канфарения. На налобной части шлема нанесено изображение Триратны, а на обруче меандрообразный орнамент алхан хээ в обрамлении гравированных фестонов-лепестков. Основные отличия шлемов из ММК и ТГИАМЗ заключаются в оформлении некоторых отдельных деталей. Так, например, обруч «тобольского» шлема выкован из одной железной полосы, склепанной на затылке. Для крепления бармицы на обруче шлема из ТГИАМЗ пробиты не 10, а 18 отверстий. Ряд фестонов-лепестков обрамляет меандрообразный орнамент на обруче только сверху (а не сверху и снизу, как на шлеме из ММК). Раструб плюмажной трубки-втулки имеет ровный, а не фестончатый край. При оформлении самой втулки использовано меньшее количество уплощенных «яблок». Вместо ромбов на пластинах тульи «тобольского» шлема изображены А-образные символы «от» выполненные письмом ланьча. Несколько отличаются детали изображения символа Триратна. Однако, несмотря на указанные различия, типологическое сходство шлемов не вызывает сомнений. Не исключено, что 




Puc. 6. «Шапка колмыцкая болшая». Вид снизу. Фото С. В. Баранова

[Fig. 6. "Big Kalmyk shapka". Bottom view. Photo by S. V. Baranov] 


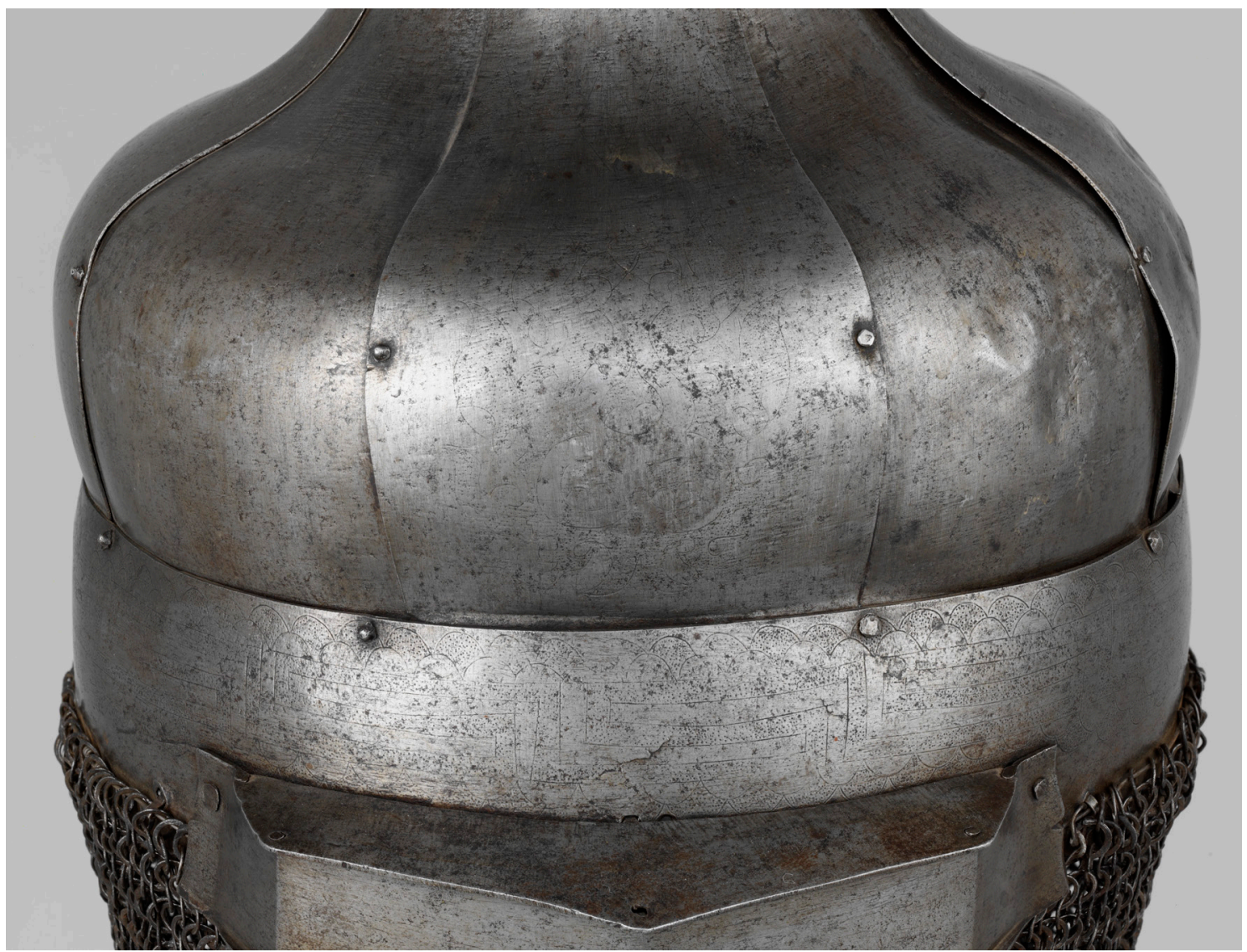

Рис. 7. «Шапка колмыцкая болшая». Налобная часть тульи, обруч и козырек. Фото С. В. Баранова

[Fig. 7. "Big Kalmyk shapka". The front of the helmet, crown and visor. Photo by S. V. Baranov] 
они были изготовлены в одном оружейном центре. В данной связи значительный интерес представляет тот факт, что шлем из ТГИАМЗ сохранил свою оригинальную бармицу ${ }^{19}$. Она имеет пластинчато-нашивную структуру бронирования и состоит из пары наушников подтрапециевидной формы и трехлепесткового назатыльника [Бобров, Худяков 2008: 441, 466, 467]. До передачи в музейное собрание «тобольский» сфероцилиндрический шлем принадлежал представителям рода Кульмаметевых. В XVII в. мурзы Кульмаметевы относились к элите тобольских служилых татар и неоднократно контактировали с представителями ойратской знати, кочевавшей на границах Западной и Южной Сибири. Так, в 1623 г. Кельмамет Якшигильдеев был включен в состав российской дипломатической миссии Д. Черкасова к дербетскому Далайтайше в качестве «вожа». В 1685 г. Сейдяш Кульмаметев занимался организацией торговли с калмыками на Ямышевом озере [Бобров, Худяков 2008: 441; Самигулов 2014: 164; Самигулов, Тычинских 2018: 99 , $104]^{20}$. Не исключено, что в ходе этих и подобных встреч татарским аристократам и были переданы ойратские шлемы, хранящиеся в настоящее время в собрании ТГИАМЗ.

Еще одним близким аналогом «Шапки колмыцкой болшой» из ММК является сфероцилиндрическое наголовье из музея искусств «Метрополитен» (инв. № 2001.91), на что совершенно справедливо указал американский исследователь Д. ЛаРокка [LaRocca 2006: 88, 89]. К сожалению, на шлеме из музея «Метрополитен» не сохранился козырек. Однако отверстия на обруче позволяют предположить, что он имел «коробчатую» конструкцию. Главным от-

${ }^{19}$ В настоящее время она прикреплена к «татарскому» шлему (инв. № ВО-70) из того же музейного собрания [Бобров, Худяков 2008: 441, 466, 467; Бобров 2009].

20 Также отметим, что в письменных источниках отмечаются факты постоянного проживания ойратов вместе с представителями родственного Кульмаметьевым семейства Сейдяшевых. Например, в 80-х гг. XVII в. вместе с тобольскими служилыми татарами Аптышем и Чемеем Сейдяшевыми проживали «...дворовые их люди купленные калмыки Мишайко Галдычко Аиткулко Лачинко[,] женаты на калмыцких же девках» [Самигулов 2014: 162]. личием указанного наголовья от шлемов из ММК и ТГИАМЗ является форма бутонообразных насадок подвершия, а также наличие «болтов» с ромбическими шляпками, с помощью которых к куполу подвешивалась пластинчато-нашивная или матерчатая бармица [Бобров, Худяков 2008: 445].

Как и другие шлемы рассматриваемой серии, наголовье ОР-2059 из собрания ММК может быть отнесено к комплексу вооружения ойратов. Таким образом, его атрибуция в документах XVII - начала XVIII вв. как «шапки колмыцкой» (то есть ойратского шлема) представляется вполне оправданной. В то же время необходимо признать, что предположение Л. П. Яковлева о том, что сфероцилиндрические шлемы из собрания Оружейной Палаты «...близко подходят видом и очертанием своим к шапкам китайскаго войска новейшаго времени» [Опись 1884: 37], является ошибочным. Как конструкция, так и оформление ойратских сфероцилиндрических шлемов имеют принципиальные отличия от конструкции и системы декоративного оформления хоу-цзиньских и цинских наголовий «чжоу» XVII-XIX вв. [Bobrov et al. 2017].

Наличие буддийской символики на «Шапке колмыцкой болшой» позволяет локализовать нижнюю границу ее изготовления вторым десятилетием XVII в., что соответствует начальному этапу широкого распространения буддийского учения среди ойратских кочевников [Златкин 1983: 101, 102; Бобров, Орленко, 2017: 133; Bobrov, Kushkumbayev, Salnikov 2018: 452 $]^{21}$. Верхней границей следует признать начало 80-х гг. XVII в., но не позднее 1682 г., когда шлем был впервые достоверно зафиксирован в российской служебной документации при проверке Большой Государевой Казны. В то же время подчеркнем, что шлем мог поступить в царское хранилище несколько раньше 1682 г., например в середине XVII в., вместе с другими «шапками калмыцкими», которые в этот период массово передавались в сокровищницу российских самодержцев в качестве дипломатических

${ }^{21}$ Указанная нижняя граница датировки, конечно, не исключает возможности того, что некоторые другие сфероцилиндрические наголовья рассматриваемой серии могли быть изготовлены несколько раньше - во второй половине XVI - начале XVII в. 
подарков ойратской и монгольской знати, а также приобретались и взимались в качестве ясака у «кузнецких татар» Южной Сибири, традиционно изготовлявших защитное вооружение для центральноазиатских номадов [Martyushov, Shirin 2018: 918, 919; Бобров, Орленко 2020: 286-292]. К сожалению, до 1682 г. описания большинства «шапок калмыцких», хранившихся в Оружейной Палате, крайне лаконичны, что затрудняет атрибуцию рассматриваемого наголовья по документам 40-70-х гг. XVII в. ${ }^{22}$

Таким образом, наиболее вероятно, что рассматриваемая «Шапка колмыцкая болшая» из собрания ММК могла быть изготовлена ойратскими или южносибирскими мастерами («кузнецкими татарами») по заказу состоятельного ойратского воина-буддиста в 10-х - начале 80-х гг. XVII в.

Варианты реконструкции первоначального вида «Шапки колмыцкой болшой» из собрания ММК

Комплексный анализ вещественных и письменных источников позволяет реконструировать возможные варианты первоначального внешнего вида шлема ОР-2059 из собрания ММК (рис. 10).

Судя по количеству и расположению отверстий, а также конструкции и покрою бармицы практически аналогичного сфероцилиндрического шлема № ВО-171 из ТГИАМЗ, наголовья рассматриваемого типа могли быть снабжены трехчастной пластинчато-нашивной бармицей, состоявшей из пары наушников и назатыльника. Нижний слой органической основы бармицы сфероцилиндрического шлема из ТГИАМЗ представлял собой лопасть мягкой кожи, поверх которой располагалась «покрышка» шерстяной ткани зеленого цвета. С внутренней стороны бармицы крепились 23 железные пластины различных форм и размеров. Последние формировали достаточно надежное, но при этом весьма эластичное защит-

${ }^{22}$ К числу исключений относятся самые первые поступления центральноазиатских шлемов, переданных в Москву в 30-х гг. XVII в. Их описания достаточно подробны, но ни одно из них не может быть уверенно соотнесено с «Шапкой колмыцкой болшой» [Опись 1884: 35-37; Опись 2014: 105; Бобров, Орленко 2017: 127-135; Бобров, Орленко 2020]. ное покрытие. Для повышения жесткости пластины снабжались специальными ярусами и ребрами, благодаря которым они имели характерную рельефную поверхность. Большинство прямоугольных пластин крепились к органической основе бармицы с помощью пяти заклепок, расположенных крестом. По краю наушников и назатыльника была пропущена кожаная окантовка. Нижний край наушников бармицы был усилен не пластинами, а фрагментами кольчужного полотна. Данное решение, вероятно, было обусловлено тем, что во время сражения наушники стягивались и завязывались под подбородком воина. Поэтому нижний край наушников должен был обладать максимально возможной эластичностью, которую и обеспечивала кольчужная броня [Бобров, Худяков 2008: 466, 467]. Не исключено, что схожую или аналогичную бармицу мог первоначально иметь и шлем из ММК (рис. 10).

Матерчатый подшлемник крепился непосредственно к тулье или, более вероятно, представлял собой отдельный головной убор. Подобные стеганые подшлемники на подкладке (иногда снабженные наушниками и назатыльниками) известны по среднеазиатской иконографии XVII в. и подлинным цинским образцам позднего Средневековья и раннего Нового времени [Bobrov et al. 2017: 1166]. Для дополнительной фиксации столь высокого шлема на голове владельца, вероятно, применялись матерчатые ленты или кожаные ремни, завязывавшиеся или застегивавшиеся под подбородком (рис. 10).

Основным видом плюмажа ойратских воинов был знаменитый улан зала, представлявший собой кисть из матерчатых лент, как правило, красного цвета [Бобров, Худяков 2008: 473]. Указанная кисть могла вставляться во втулку шлема или подвешиваться к бутонообразным насадкам на подвершии. В последнем случае втулку шлема мог украшать перьевой султан (рис. 10). Также использовались кисти из конского волоса и шерсти яка, флажки различных типов, а во время торжественных церемоний и сложные составные конструкции [Бобров, Худяков 2008: 473, 475, 476].

Как уже отмечалось выше, при проверке Большой Государевой Казны 1682 г. «Шапка колмыцкая болшая» была уже (или 


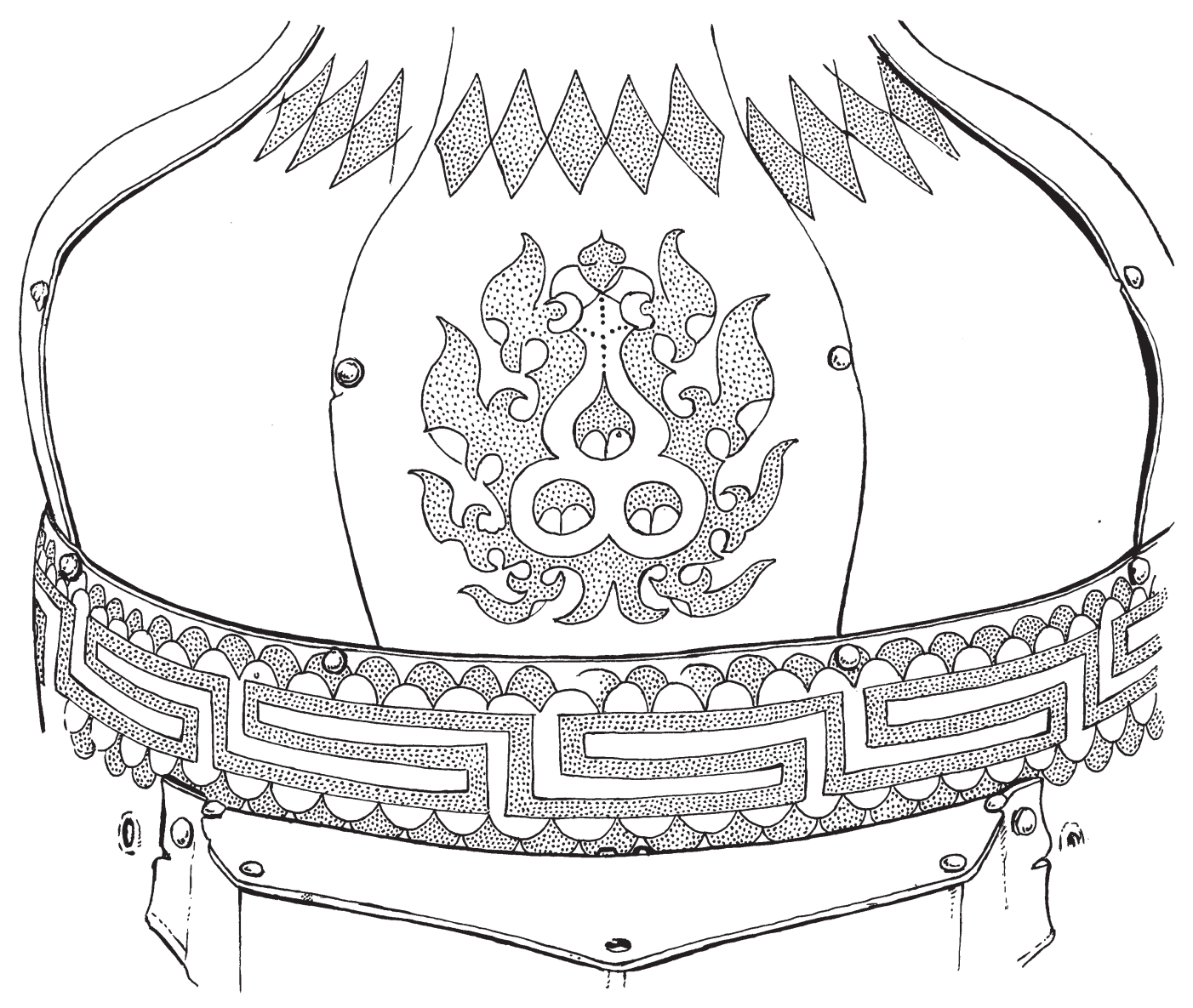

Puc. 8. Прорисовка изображений на тулье и обруче «Шапки колмыцкой болшой». Рис. Л. А. Боброва

[Fig. 8. Drawing of images on the forehead of the "Big Kalmyk shapka". Drawing by L. A. Bobrov] 


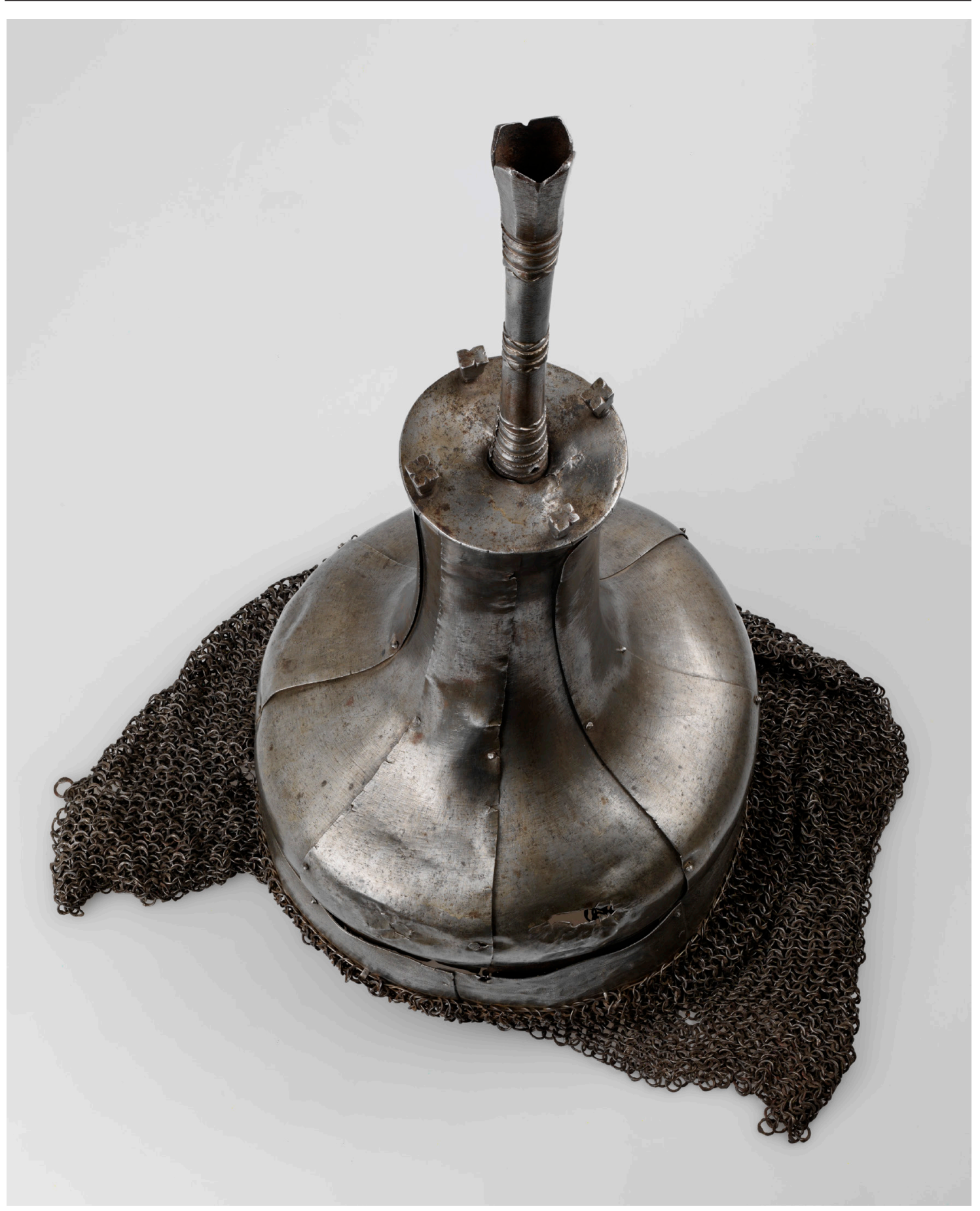

Рис. 9. «Шапка колмыцкая болшая». Вид сверху. Фото С. В. Баранова

[Fig. 9. "Big Kalmyk shapka". View from above. Photo by S. V. Baranov] 
Oriental Studies. 2020. Vol. 13. Iss. 5

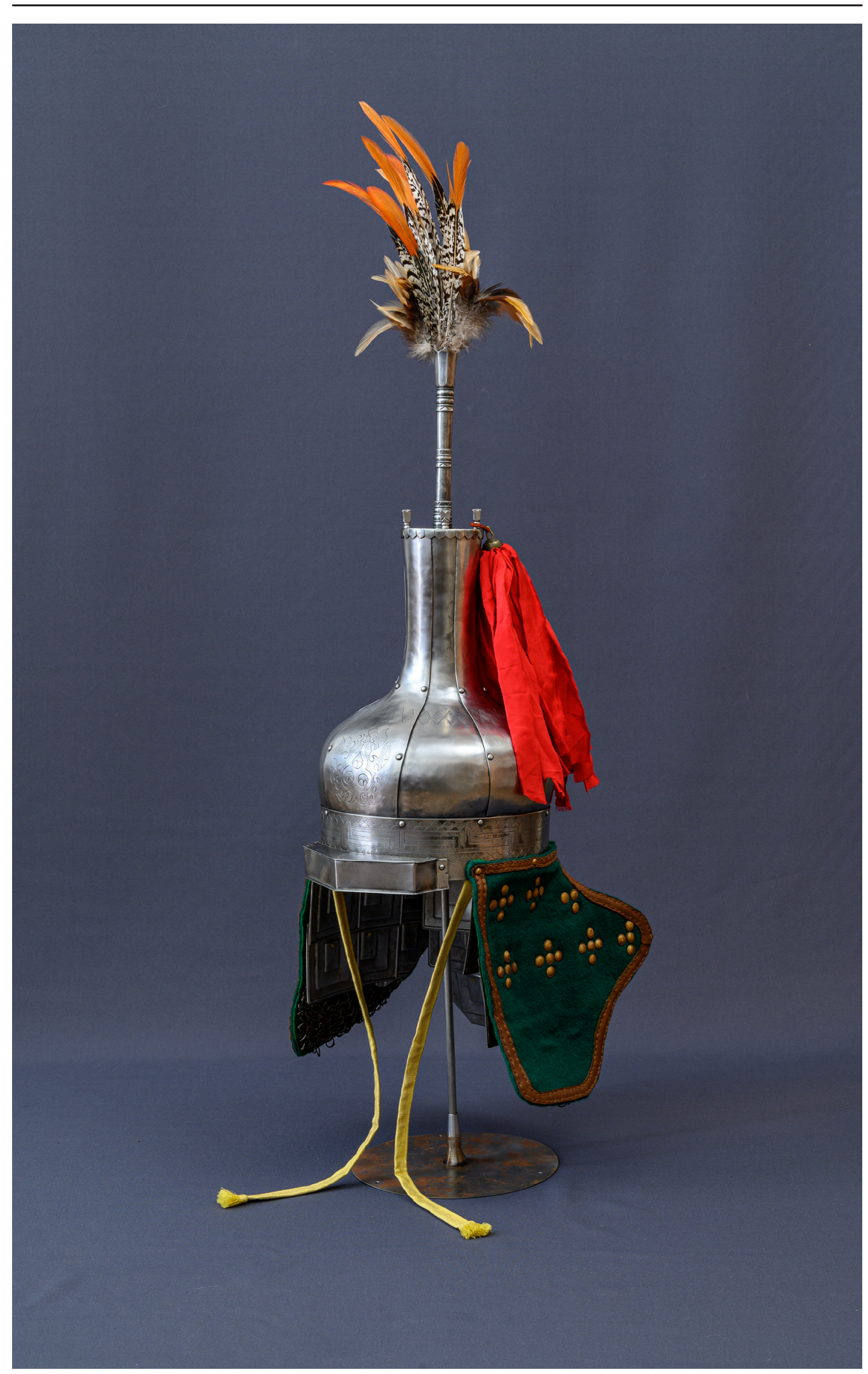


еще) «невооружена», то есть не имела бармицы и подшлемника [Опись 1884: 36]. Неизвестно, отсутствовали они на шлеме уже в момент передачи его русским или по каким-то причинам были удалены в период нахождения наголовья в царских хранилищах. Так или иначе, но к моменту составления Описи 1687 г. данные элементы уже были добавлены к шлему. Наиболее вероятно, что они были изготовлены московскими мастерами $^{23}$. Составить представление о том, что включало «вооружение» шлема ОР2059 позволяет сообщение описи 1727 г.: «...одного наушня і подкладки кумашной нет» [Опись 1884: 36]. Таким образом, наголовье имело «кумашный» (красный) матерчатый подшлемник, пару «наушников» и, возможно, назатыльник.

Как показал анализ русской служебной документации, при изготовлении бармиц к «шапкам калмыцким» московскими мастерами использовались пластины («доски железные», «полицы», «шапочные полицы») и заклепки («гвозди») центральноазиатского и южносибирского производства, переданные из Сибирского Приказа, а также выкованные непосредственно в Оружейной Палате. Учитывая, что пластинчато-нашивные бармицы были не характерны для российского комплекса защитного вооружения XVII в.,

23 «А по нонешней переписи 195 году и по осмотру та шапка против прежних переписных книг сошлась, а по осмотру та шапка вооружена, цена полтина» [Опись 1884: 36]. можно предположить, что в качестве образца для придворных мастеров выступали оригинальные бармицы центральноазиатского производства, которые сохранились на некоторых монгольских и ойратских шлемах, поступивших в царские хранилища [Бобров, Орленко 2020: 293-295]. В описи 1687 г. упомянуты 86 «колмыцких» шлемов снабженных пластинчато-нашивными бармицами с «покрышкой» из красного, зеленого и черного бархата: «Восемьдесят шесть шишаков колмыцких сшивных, наушники белаго железа ${ }^{24}$ обложены сверху бархатом червчатым и зеленым и черным, в том числе один шишак целной кованой[,] задка и наушника и трубки нет, цена по десяти алтын» [Опись 1884: 38]. Весьма вероятно, что подобной бармицей мог быть снабжен и сфероцилиндрической шлем, рассматриваемый в настоящей работе.

Не исключено, что «Шапка колмыцкая болшая» была также дополнена «лопастя-

\footnotetext{
24 «Белое железо» (или «немецкое железо») представляло собой разновидность толстой жести. Использовалось в Оружейной Палате в XVII в. для доукомплектования имевшихся в казне «невооруженных» шлемов для последующего использования в парадно-церемониальных мероприятиях русского двора. Подобные «вооруженные» наголовья (в том числе и «шапки калмыцкие») выдавались царским конюхам и иным чинам для участия во встречах иностранных послов, военных смотрах и др. [Бобров, Орленко 2020: 293-299].
}

Puc. $\overline{10}$. Научно-историческая реконструкция «Шапки колмыцкой болшой». Авторы реконструкции: Л. А. Бобров, Ю. А. Филиппович (мастер). Шлем представляет собой копию наголовья ОР2059 из собрания Музеев Московского Кремля (восстановлены затертые гравированные изображения на тулье и обруче). Он снабжен трехчастной пластинчато-нашивной бармицей, выполненной по образцу бармицы аналогичного сфероцилиндрического шлема из собрания Тобольского государственного историко-архитектурного музея-заповедника (инв. номер: ВО-171), сохранившей как органическую основу, так и подбой из рельефных железных пластин. Шлем снабжен подшлемником и подбородочными завязками. Во втулку вставлен перьевой султан. К лотосообразным насадкам на подвершии подвешена традиционная для ойратов кисть из красных шелковых лент - улан зала.

[Fig. 10. Scientific and historical reconstruction of 'Kalmyk shapka bolshaya'. Authors of the reconstruction: L. A. Bobrov, Yu. A. Filippovich. Craftsman: Yu. A. Filippovich. The helmet is a copy of the OR2059 headpiece from the MKM collection (worn-out engraved images on the crown and brim have been restored). It is equipped with a three-part lamellar-sewn aventail, created in the image of the model of the aventail of a similar spherocylindrical helmet from the TGIAMZ collection (Inventory No. VO-171), which retained both an organic base and a lining made from linear corrugated iron plates. The helmet is equipped with a comforter and chin straps. A feather plume is inserted into the sleeve. The traditional Oirats' brush made of red silk ribbons - 'ulan zala' is suspended from the lotus-shaped attachments on the underside] 
ми» из атласа и тафты ${ }^{25}$, которые завязывались под подбородком. Во второй половине XVII в. подобные подбородочные ленты массово изготовлялись московскими мастерами для «шапок калмыцких» хранившихся в Оружейной Палате [Бобров, Орленко 2020]. Аналогичные или похожие «лопасти» из красных и желтых атласных (?) лент можно наблюдать на рисунках Ф. Г. Солнцева с изображением русских шлемов, хранившихся в Оружейной Палате в XIX в., но не пострадавших в пожаре 1737 г. [Броня 2015: 8, 9, 11, 13, 16-18].

Во втулки «шапок калмыцких», предназначенных для применения в придворных церемониях, вставлялись специальные цветные флажки, так называемые «прапорцы» и «прапорчики». Так, например, в преддверии грандиозного военного смотра на Девичьем поле в 1664 г. «живописцу» С. Лопуцкому были выделены «...сученово жолтово шолку два золотника. Шил тридцать прапорцов тафтяных и писал по золоту красками к калмыцким шапкам» [цит. по: Бобров, Орленко 2020: 294].

Традиция украшения наверший шлемов цветными флажками — «яловцами» - получила широкое распространение среди народов мусульманского Востока, а затем и Восточной Европы в XV-XVI вв. Однако совершенно не очевидно, что «прапорцы», вставлявшиеся во втулки «шапок калмыцких», восходили именно к «яловцам». Шлемы воителей-буддистов также украшались флажками различных типов, зафиксированных в материалах буддийской иконографии позднего Средневековья и раннего Нового времени: «Как эмблема войны флаг обычно имеет форму треугольного шелкового вымпела (тиб. dar khru) с зубчатой кромкой из войлока, шелка, хлопка или тонкой кожи. Многие воинственные божества, такие как Гесар из Линга, Бегце или Циу Марпо носят маленький флаг в качестве украшения на шлеме. Эти флаги выглядят как симметричные пары треугольников из разноцветного шелка, которые развеваются, подобно крыльям бабочек или парусам

25 Тафта (фр. taffetas, итал. taffeta, от перс. - скрученный, свитый, сотканный) - разновидность глянцевой плотной тонкой ткани полотняного переплетения из туго скрученных шелковых или хлопковых нитей. Для тафты характерны жесткость, плотность , а также ломкость складок. корабля. К внешним краям этих флагов на шлемах часто прикрепляются маленькие пучки белой шерсти, символизирующие облака (белые пучки), плывущие по небу (пространство флага). На вершине шлема божества часто имеется знак маленького наконечника копья или меча, драгоценность, красный хвост яка, пучок белой шерсти, перья павлина или маленькое победоносное знамя. Флаги на шлемах стратегически использовались тибетскими и монгольскими воинами для создания иллюзии того, что воин, на котором этот шлем, более грозный, чем на самом деле» [Бир 2013: 226, 227].

Таким образом, известные материалы позволяют с высокой степенью достоверности реконструировать внешний вид изучаемого шлема, как в его возможной первоначальной комплектации (рис. 10), так и в момент нахождения в Оружейной Палате Московского Кремля.

Обстоятельства и причины появления сфероцилиндрических илемов в комплексе защитного вооружения ойратов

В завершении необходимо хотя бы кратко остановиться на причинах появления шлемов столь необычной формы в комплекce вооружения ойратских (джунгарских, калмыцких и др.) воинов эпохи позднего Средневековья и раннего Нового времени.

Как показали экспериментальные испытания, сфероцилиндрическое наголовье не имеет каких-то ярко выраженных функциональных преимуществ перед своими сфероконическими или полусферическими аналогами. Более того, сильные рубящие горизонтальные удары по вытянутой цилиндрической части тульи создавали дополнительные риски для хозяина «кувшинообразного» шлема [Бобров, Худяков 2003: 144; Худяков, Бобров, Филиппович 2005: 98100]. Тем не менее сфероцилиндрические наголовья продолжали активно применяться состоятельными ойратами, воевавшими на территории Восточной Европы, Южной Сибири, Средней и Центральной Азии ${ }^{26}$.

26 Значительный интерес представляет тот факт, что весьма схожие (иногда даже аналогичные) по конструкции и системе оформления сфероцилиндрические шлемы происходят из разных регионов Евразии, ставших объектом ойратской экспансии (Поволжье, южные районы Западной Сибири, Юго-Восточный Казахстан, Тибет, Западная Монголия и др.). 
В чем же причина данного военно-исторического феномена?

В первую очередь необходимо отметить, что основное функциональное преимущество сфероцилиндрического шлема является оборотной стороной его главного технологического недостатка. Шлем с высокой вытянутой тульей, увенчанной длинной трубкой-втулкой с плюмажом из лент или перьевого султана, был хорошо заметен на поле боя ${ }^{27}$. В ходе динамичного конного сражения подобный шлем помогал воинам подразделения быстро определить местоположение своего командира, что, вероятно, облегчало управление войсками во время битвы [Бобров, Худяков 2003: 144] ${ }^{28}$.

Однако, на наш взгляд, факт появления шлемов сфероцилиндрической формы был обусловлен не только (а, возможно, и не столько) технологическими и функциональными, но и культурно-религиозными причинами. Во второй половине XVI - начале XVII в. среди монголоязычных кочевников Центральной Азии стремительно распространяется буддизм, что приводит к важным изменениям как в духовной жизни, так и в материальной культуре номадов [Златкин 1983: 98-103; Бобров, Орленко 2017; Bobrov, Kushkumbayev, Salnikov 2018: 449, 451, 452]. Буддийской символикой начинают все чаще дополняться не только повседневный и парадный костюм, но и предметы защитного воору-

27 Напомним, что общая высота рассматриваемого шлема ОР-2059 из ММК достигает 49,5 см. И это не считая перьевого султана, флажка или кисти, которые вставлялась во втулку «Шапки колмыцкой болшой». Тем не менее, несмотря на внушительные размеры, сфероцилиндрические шлемы не могут быть атрибутированы как сугубо парадные церемониальные наголовья. В пользу их боевого назначения свидетельствуют не только особенности конструкции, следы рубящих и дробящих ударов на их поверхности, но и наличие типичных для боевых наголовий видов бармиц (в первую очередь с пластинчато-нашивной структурой бронирования).

28 Декоративное оформление и конструкция сфероцилиндрических шлемов свидетельствуют в пользу того, что владельцами подобных наголовий являлись состоятельные ойратские воины, в том числе представители командного состава калмыцких и джунгарских армий. жения воинов Великой степи. До нашего времени дошли многочисленные монгольские и ойратские шлемы и панцири, покрытые буддийскими мантрами, символами Триратна, изображениями Будды, докшидов - свирепых божеств, цветков лотоса, ваджр, свастики, буддийских ступ и др. [Ленц 1895: табл. V, 171; LaRocca 1999: 115, 116; LaRocca 2006: 75-78, 80, 81, 83, 84, 88-91; Бобров, Худяков 2008: 433, 440-446, 452, 454, 460-462; Бобров, Ожередов 2010: 16-20, 30, 33, 34, 36, 38, 40, 42-45, фото 1, 2, 5-10; Бобров, Орленко 2017; Bobrov, Kushkumbayev, Salnikov 2018: 449, 451, 452]. В некоторых случаях отдельные конструктивные элементы наголовий и корпусных доспехов также изготовлялись в виде буддийских символов. Так, например, фиксаторы бармицы на ойратском шлеме ГИН 148 из собрания Акмолинского областного историко-краеведческого музея (АОИКМ, г. Кокшетау, Республика Казахстан) выполнены в форме А-образных пластинок, символизирующих санскритский слог ma [Bobrov, Kushkumbayev, Salnikov 2018: 449, 451, 452]. Схожим образом были оформлены и сотни металлических накладок панцирных пластин джунгарского доспеха из собрания Музея археологии и этнографии Сибири Томского государственного университета [Бобров, Ожередов 2010: 16-20, 30, $33,34,36,38,40,42-45$, фото 1, 2, 5-10]. Крайним проявлением данной тенденции стало стремление придать боевому наголовью форму головного убора буддийского священнослужителя. В. Бехаймом было опубликовано изображение клепанного ойратского шлема, хранящегося в музее Польди-Пеццоли (г. Милан, Италия), изготовленного в виде колпака буддийского ламы [Бехайм 1995: 47, рис. 43] 29. $^{29}$

Нам представляется, что феномен сфероцилиндрических шлемов следует рассматривать именно в этом «религиозно-оружейном» контексте. Проведенный анализ показал, что силуэт сфероцилиндрических наголовий в значительной степени повторяет контур традиционной буддийской ступы - субургана (монг. суварга(н), калм. суврhн) - одного из важнейших символов

${ }^{29}$ Первоначально наголовье было ошибочно атрибутировано как «Простой татарский шлем» [Бехайм 1995: 47, рис. 43]. 


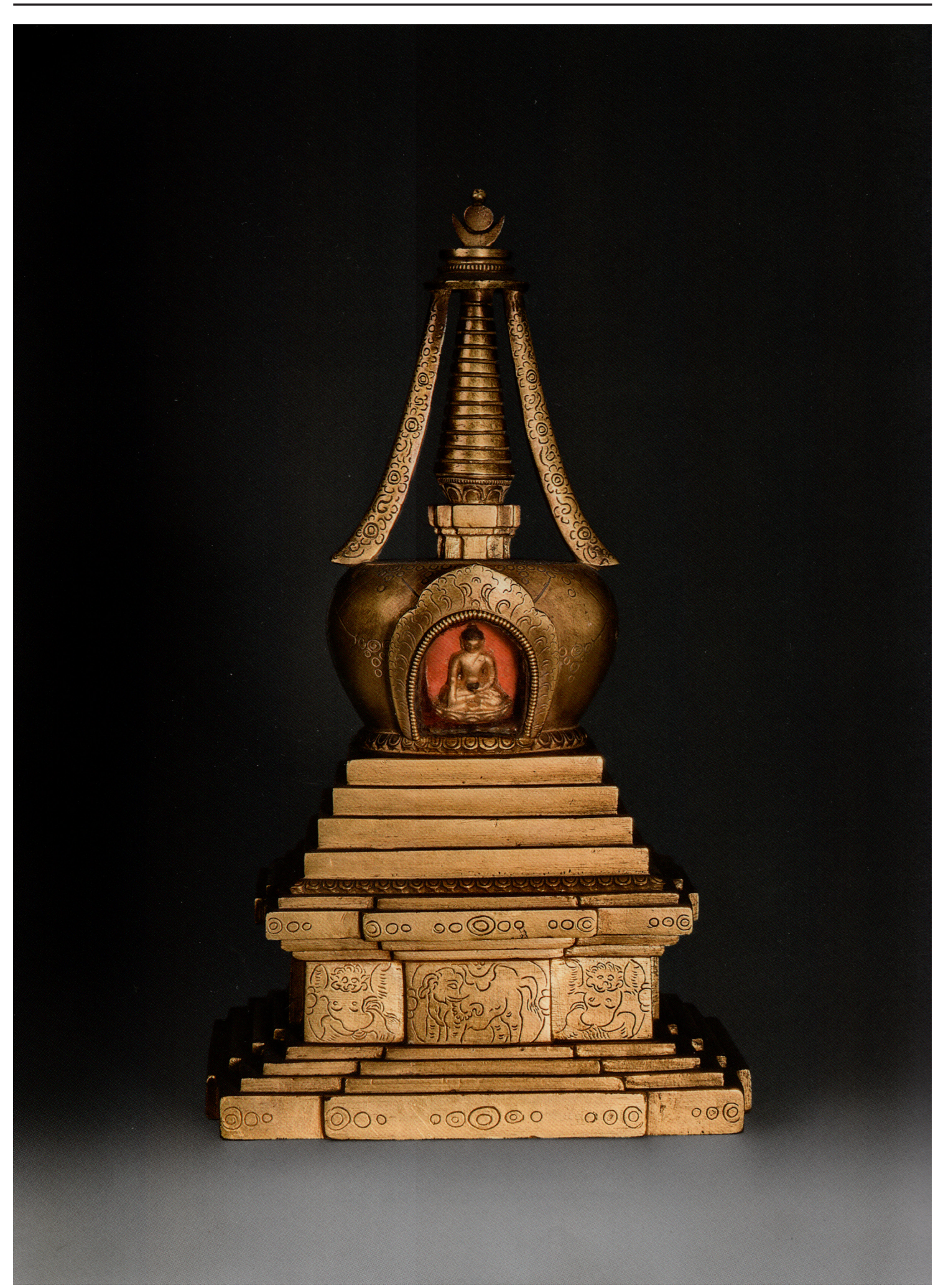

Puc. 11. Буддийская ступа. Школа мастера Дзанабадзара. Монголия. Начало XVIII в. Государственный Эрмитаж (инв. номер: У-1463). (Из каталога «Обитель милосердия». Искусство тибетского буддизма. СПб.: Изд-во Гос. Эрмитажа, 2015)

[Fig. 11. Buddhist stupa, school of master Dzanabadzar, Mongolia, early 18th century, Inv. No. U-1463, State Hermitage Museum (after: Abode of Mercy, 2015)] 
«желтой веры» (монг. шар шашин) $)^{30}$ и буддийского учения в целом (рис. 11). В рамках данной религиозной традиции ступа символизирует «созидательную способность и незыблемость Учения», а также служит «... одним из семантических заместителей образа Будды» [Кравцова 2004: 466]. В качестве культового сооружения ступа, помимо прочего, выполняет функцию «... вотивного объекта, возводимого по обету ради выполнения религиозной заслуги», а также, что особенно важно для нашей темы, - «символа учения Будды» [Хижняк 2008: 57].

При подобной интерпретации полусферическая часть тульи шлема будет соответствовать полусферической части ступы, так называемой «вазе», символизирующей семь ветвей Пробуждения («Путей видения»): глубокую внимательность, глубокое распознавание явлений, глубокое усердие, глубокую радость, глубокий навык, глубокою медитацию и глубокую уравновешенность. В то же время цилиндрическая часть тульи будет соответствовать Древу жизни, символизирующему различные аспекты мудрости Будды. Согласно заветам «желтой веры», ступа становится для верующего опорой духа, сердца, сознания, тела, а также обозначает образ Будды, бодхисаттвы, учителя. Своей внешней формой различные части ступы олицетворяют пять элементов: землю, воду, огонь, воздух (ветер) и солнце (пространство) [Обитель милосердия 2015: 454-457].

Первичное сопоставление декоративного оформления поверхности ступ с узорами и орнаментами на поверхности некоторых сфероцилиндрических шлемов (в том числе и рассматриваемого в настоящей статье) подтвердило данное предположение. Так, например, четыре ступени, расположенные под «вазой» монгольской ступы начала XVIII в. из собрания Государственного Эрмитажа, обрамлены изображениями лепестков лотоса (рис. 11). Аналогичные лепестки нанесены и по краям обруча шлема из ММК, который расположен непосредственно под полусферической частью ту-

30 Шар шашин - монгольское название буддийского монастырского образования и ритуальной практики, также известного, как школа Гелуг (Гелугпа). Была основана в Тибете ламой Чже Цонкапой (1357-1419). При принятии буддизма подавляющая часть ойратов стала последователями именно школы Гелуг. льи, соответствующей полусферической «вазе» субургана (рис. 7, 8, 11). Традиция нанесения лепестков лотоса в два ряда, которые можно видеть на обруче «Шапки колмыцкой болшой», фиксируется и на буддийских тибетских ступах развитого и позднего Средневековья [Обитель милосердия 2015: 454, 455].

В свою очередь характерная форма полусферической части шлема весьма напоминает контур «вазы» буддийской «ступы» (рис. 2-5, 11). По центру лицевой стороны ступ, посвященных просветлению Будды, в специальной нише размещалось его фигурное изображение (рис. 11). Выполнить аналогичное изображение на налобнике боевого наголовья, по всей видимости, было технологически затруднительно. Тем не менее, мастер выгравировал на налобной части шлема символическое изображение Триратны — Трех драгоценностей буддизма, олицетворяющих собой «...тело, речь и ум всех будд» [Бир 2013: 78].

Вытянутая цилиндрическая часть шлема соответствует «шпилю» ступы и соотносится с огнем. В подтверждение этой аналогии отметим, что поверхность цилиндрической части шлема из ТГИАМЗ украшена изображениями языков пламени [Бобров, Худяков 2008: 440, рис. $173,1,2 ; 441,174$, рис. 174 , 1; 460, рис. 190, 2].

Так же, как «шпиль» ступы венчает округлый плоский «зонт» (рис. 11), так и цилиндрическая часть шлема покрыта плоским крышкообразным подвершием (рис. 2-4, 9). Согласно традиции, буддийский зонт (тиб. gdugs) по периметру имел «...плиссированный шелковый фриз с множеством разноцветных шелковых оборок и подвесок», которые часто изображались в виде вырезных остроугольных фестонов [Бир 2013: 22, 24, 25, 224]. Близкие по форме остроугольные фестоны можно наблюдать и на бортике подвершия шлема из ММК (рис. 2-5). По мнению буддистов, «прохлада тени зонта символизирует защиту от болезненного жара страдания, страсти, препятствий, болезней и вредоносных сил» [Бир 2013: 24]. Все эти свойства буддийского зонта были далеко не бесполезны носителю шлема во время дальних походов и сражений. Кроме того, зонт не только олицетворял «почет и уважение», но и являлся символом «царской власти и защиты» [Бир 
2013: 24]. Учитывая наше предположение, что владельцем «Шапки колмыцкой болшой» был высокопоставленный воин, облаченный властью, аллегорический образ «зонта» на его наголовье выглядит весьма уместным.

Вершина буддийского зонта украшалась «маленьким золотым лотосом, сосудом и драгоценностью» [Бир 2013: 24]. На поверхности подвершия шлема (предположительно символизирующего буддийский зонт) размещена трубка-втулка для плюмажа, выполненная в виде распустившегося лотоса в окружении четырех цветочных бутонов. Сочетание зонта и лотоса также обусловлено буддийской традицией. Оба они входят в число Восьми благоприятных символов ${ }^{31}$, которые традиционно изображались на различных изделиях, в том числе изготовленных из металла [Бир 2013: 24].

Многочисленные совпадения деталей оформления элементов сфероцилиндрического шлема и буддийских ступ позволяют предположить, что они вряд ли являются случайными. Весьма вероятно, что мастер, изготовивший и оформивший наголовье, вдохновлялся именно образом ступы, являющейся одним из самых ярких символов учения Будды. Не исключено, что необычный для боевых наголовий сфероцилиндрический купол шлема, напоминающий форму буддийской ступы, должен был не только подчеркивать верность воина заветам «желтой веры», но и защитить его владельца как от оружия противника, так и от вражеского магического воздействия.

В данной связи необходимо отметить, что мастер весьма удачно совместил в шлемовых элементах функциональноутилитарные технологические решения и символьные значения. Так, например, бутонообразные насадки на подвершии не только олицетворяют священный лотос, но и одновременно соединяют подвершие с пластинами тульи, обеспечивая конструкции купола шлема необходимую жесткость. Кроме того, форма данных насадок позво-

31 Восемь благоприятных символов (тиб. bkra shis rtags brgyad): зонт, золотые рыбы, coсуд, лотос, раковина, закручивающаяся вправо, узел без начала и конца, знамя победы, колесо с восемью спицами. Они могли «...изображаться по отдельности, парами, по четыре и составной группой из восьми» [Бир 2013: 23]. ляла использовать их для подвешивания элементов плюмажа шлема, например кисти улан зала (рис. 10). Не исключено, что к ним, по аналогии со ступой Просветления (рис. 11), могли также крепиться и длинные, украшенные орнаментом, шелковые ленты, ниспадавшие на тулью шлема. Круглая крышкообразная пластина подвершия не только символизировала буддийский зонт, но и одновременно являлась одним из важнейших элементов конструкции шлема, стягивавшим и фиксировавшим пластины тульи сверху. Если принять предположение о символике шлема, соответствующей символике ступы-субургана, то обручу шлема соответствует та часть ступы, которая символизирует четыре ступени накопления и соединения. Обруч был обрамлен с двух сторон гравированными лепестками лотосов и в то же время представлял собой основу для крепления бармицы шлема и дополнительно фиксировал пластины тульи в нижней части наголовья.

\section{Выводы}

Проведенный анализ позволил уточнить датировку и атрибуцию «Шапки колмыцкой болшой» (ОР-2059) из собрания ММК. Установлено, что шлем входит в состав большой группы ойратских сфероцилиндрических («кувшинообразных», «вазообразных») наголовий, датируемых периодами позднего Средневековья и раннего Нового времени. Весьма вероятно, что мастера, изготовившие шлемы указанной серии, вдохновлялись образом буддийской ступы-субургана. Особенности конструкции, системы оформления наголовья (в том числе наличие буддийской символики), а также материалы русской служебной документации 80-х гг. XVII в. позволяют предположить, что рассматриваемая «Шапка колмыцкая болшая» была изготовлена ойратскими или южносибирскими оружейниками для состоятельного ойратского воина-буддиста в 10-х - начале 80-х гг. XVII в., но не позднее 1682 г., когда шлем был впервые достоверно зафиксирован в российской служебной документации при проверке Большой Государевой Казны.

Высокая научная ценность рассматриваемого шлема обусловлена не только его хорошей сохранностью, но и тем фактом, что он может выступать в качестве эталона при датировке и атрибуции других ой- 
ратских наголовий из российских и иностранных музейных и частных собраний. Гравированные рисунки, нанесенные на поверхность тульи и обруча шлема ОР-2059, могут представлять собой один из самых ранних известных образцов ойратского изо-

\section{Источники}

Древности 1853 - Древности Российского государства, изданные по высочайшему повелению государя императора Николая I. Отд. III: Броня, оружие, кареты и конская сбруя: альбом / Рисованы ак. Ф. Солнцевым. М.: Тип. Александра Семена, 1853. 152 c.

Опись 1884 - Опись Московской Оружейной палаты. Ч. 3. Кн. 2: Броня [сост. Л. П. Яковлевым]. М.: Тип. О-ва распространения полезных книг, 1884. 312 с.

Опись 2014 - Опись царской казны на Казенном дворе 1640 года. М.: Гос. ист.-культ. му-

\section{Sources}

Moscow Kremlin Museums; Department of Manuscript, Graphic and Printed Collections. Coll. 1 (Kremlin Armory). (In Russ.)

Russian State Archive of Ancient Acts. Coll. 396 (Archive of the Kremlin Armoury). (In Russ.)

Russian State Historical Archive. Coll. 468 (Cabinet of His Imperial Majesty, Ministry of the Imperial Court). (In Russ.)

Antiquities of the Tsardom of Russia: Published by Supreme Order of Emperor Nicholas I. Vol. III: Body Armor, Weapons, Carriages, and Horse

\section{Литература}

Анисимова 2013 - Анисимова M. А. Оружие Востока XV - первой половины XX века: из собрания Военно-исторического музея артиллерии, инженерных войск и войск связи. СПб.: Атлант, 2013. 527 с.

Ахметжан 2007 - Ахметжан К. С. Этнография традиционного вооружения казахов. Алматы: Алматыкитап, 2007. 216 с.

Бехайм 1995 - Бехайм В. Энциклопедия оружия. СПб.: Санкт-Петербург оркестр, 1995. $576 \mathrm{c}$.

Бир 2013 - Бир Р. Тибетские буддийские символы: справочник. М.: Ориенталия, 2013. $336 \mathrm{c}$.

Бобров 2009 - Бобров Л. А. «Татарский» шлем с комбинированной бармицей из Тобольского государственного историко-ар- бразительного искусства XVII в. Учитывая данные факты, не будет большим преувеличением сказать, что «Шапка колмыцкая болшая» может по праву считаться одной из важных исторических и культурных реликвий калмыцкого народа.

зей-заповедник «Московский Кремль», 2014. 192 c.

ОРГПФ ММК - Отдел рукописных графических и печатных фондов Музеев Московского Кремля Ф. 1 (Московская Оружейная палата).

РГИА - Российский государственный исторический архив. Ф. 468 (Кабинет императорского величества Министерства императорского двора (МИДв)).

РГАДА - Российский государственный архив древних актов. Ф. 396 (Архив Московской Оружейной палаты).

Рисунки 1884 - Рисунки к Описи Московской Оружейной палаты. М.: [б. и.], 1884. 500 с.

Tack. Acad. F. Solntsev (drawings). Moscow: A. Semen, 1853.152 p. (In Russ.)

Treasury of the Tsardom of Russia: 1640 Inventory Catalogue of the Treasury Yard (Dvor). Moscow: Moscow Kremlin Museums, 2014. 192 p. (In Russ.)

Yakovlev L. P. (comp.) Inventory Catalogue of the Kremlin Armoury. Vol. 3. Book 2: Body Armor. Moscow: Society for the Distribution of Useful Books, 1884. 312 p. (In Russ.)

Inventory Catalogue of the Kremlin Armoury: Drawings. Moscow, 1884. 500 p. (In Russ.)

хитектурного музея-заповедника // Вестник Новосибирского государственного университета. Сер.: История, филология. 2009. Т. 8. Вып. 3. С. 251-254.

Бобров 2014 - Бобров Л. А. «Воронья стая» над Крымом. Татарско-калмыцкое противоборство в степях Северного Причерноморья (сентябрь 1661 - январь 1663 гг.) // Средневековые тюрко-татарские государства. 2014. № 6. С. 239-249.

Бобров, Зайцев, Орленко 2017 Бобров Л. А., Зайцев В. П., Орленко С. П. Центральноазиатский «Шелом булатной» конца XVI - первой трети XVII в. из числа даров Эрдэни Дай мэргэн Нансо // Археология евразийских степей. 2017. № 5. С. 216-230.

Бобров, Ожередов 2010 - Бобров Л. А., Ожередов Ю. И. Позднесредневековый 
панцирь-«халат» воина-буддиста (Из истории «оружейного» собрания Музея археологии и этнографии Сибири Томского гос. ун-та) // Материалы и исследования Древней, Средневековой и Новой истории Северной и Центральной Азии / отв. ред. Ю. И. Ожередов. Т. ІІІ. Вып. 1. Томск: Томский гос. ун-т, 2010. С. 7-64.

Бобров, Орленко 2017 - Бобров Л. А., Орленко С. П. Монгольский шлем конца XVI - первой трети XVII вв. из собрания Оружейной Палаты Московского Кремля // Археология, этнография и антропология Евразии. 2017. № 4. С. 127-135.

Бобров, Орленко 2020 - Бобров Л. А., Орленко С. П. «Шапки калмыцкие» в собрании Оружейной палаты Московского Кремля // Oriental Studies. 2020. № 2. С. 278 304.

Бобров, Рюмшин 2015 - Бобров Л. A., Рюмшин М. А. «...И против них не стаивали они нигде и биться с ними не умеют». Оружейный и военно-тактический аспект калмыцко-ногайских и калмыцко-татарских войн первой половины - середины XVII в. // Золотоордынская цивилизация. 2015. № 8. C. $357-378$.

Бобров, Худяков 2003 - Бобров Л. А., Худяков Ю. С. Боевые наголовья кочевников Монголии и Калмыкии второй половины XVI - начала XVIII в. // Древности Алтая. 2003. № 11. С. 138-155.

Бобров, Худяков 2008 - Бобров Л. А., Худяков Ю. С. Вооружение и тактика кочевников Центральной Азии и Южной Сибири в эпоху позднего Средневековья и Нового времени (XV - первая половина XVIII вв.). СПб.: Фак-т филологии и искусств СПбГУ, $2008.770 \mathrm{c}$.

Броня 2015 - Броня, оружие, кареты и конская сбруя. Рисунки Ф. Солнцева: [альбом]. СПб.: Белый город, 2015. 146 с.

Вельтман 1844 - Вельтман А. Ф. Московская Оружейная палата. М.: Тип. И. Степанова, 1844. 172, 74, VIII с., 33 л. ил.

Вельтман 1860 - Вельтман А. Ф. Московская Оружейная палата. 2-е изд., вновь составленное. М.: Тип. Бахметева, 1860. 288 с.

Горелик 1979 - Горелик М. В. Средневековый монгольский доспех // Третий международный конгресс монголоведов. Улан-Батор, 1979. С. 76-97.

Горелик 1983 - Горелик М. В. Монголотатарское оборонительное вооружение второй половины XIV - начала XV в. // Куликовская битва в истории и культуре нашей Родины. М.: Изд-во МГУ, 1983. С. 244269.

Горелик 1987 - Горелик M. В. Ранний монгольский доспех (IX - первая половина XIV вв.) // Археология, этнография и антропология Монголии. Новосибирск: Наука, 1987. C. 163-208.

Горелик 2002 - Горелик М. В. Армии монголо-татар X-XIV вв. Воинское искусство, снаряжение, оружие. М.: Восточный горизонт, 2002. 84 c.

Златкин 1983 - Златкин И. Я. История Джунгарского ханства (1635-1758). М.: Наука, 1983. 332 с.

Историческое описание... 2008 - Историческое описание одежды и вооружения российских войск. Ч. 1. М.: Кучково поле, 2008. 168 с.

Кравцова 2004 - Кравичова М. Е. Мировая художественная культура. История искусства Китая. СПб.: Лань, TPIADA, 2004. 960 с.

Ленц 1895 - Лени Э. Опись собрания оружия графа С. Д. Шереметьева. СПб.: Тип. М. Стасюлевича, 1895. 223 с.

Обитель милосердия 2015 - «Обитель милосердия». Искусство тибетского буддизма: каталог выставки. СПб.: Изд-во Гос. Эрмитажа, 2015. $512 \mathrm{c}$.

Самигулов 2014 - Самигулов Г. Х. Сейдяшевы и Кульмаметевы - попытки реконструкции // Присоединение Сибири к России: новые данные. Тюмень: Изд-во Тюмен. гос. ун-та, 2014. С. 162-166.

Самигулов, Тычинских 2018 - Самигулов Г. Х., Тычинских 3. А. Новые источники по истории мурз Кульмаметьевых // Вестник археологии, антропологии и этнографии. 2018. № 1 (40). С. 99-107.

Хижняк 2008 - Хижняк О. С. Ступа: начало формирования буддийского культа. СПб.: Изд-во Санкт-Петербургского гос. ун-та, 2008. 272 c.

Худяков, Бобров, Филиппович 2005 Худяков Ю. С., Бобров Л. А., Филиппович Ю. А. Опыт экспериментальной реконструкции и функционального анализа защитного вооружения воинов Центральной Азии эпохи позднего Средневековья // Вестник Новосибирского гос. ун-та. Сер.: История, филология. 2005. Т. 4. Вып. 5. С. 95-103.

Шиндлер 2016 - Шиндлер О. В. Русские шлемы XVI века // История военного дела: ис- 
следования и источники [электронный ресурс]. 2016. T. VIII. C. 167-219. URL: http:// www.milhist.info/2016/05/10/schindler_3 (10.05.2016) (дата обращения: 07.03.2019)

Шиндлер 2018 - Шиндлер О. В. К вопросу о правомерности использования термина «шишак» в XVI веке, его происхождении и развенчании одного устаревшего мифа // История военного дела: исследования и источники [электронный ресурс]. 2018. T. X. C. 163-187. URL: http://www.milhist. info/2018/09/24/schindler_6 (дата обращения: 16.02.2020)

Bobrov et al. 2017 - Bobrov L. A., Zaytsev V. P., Orlenko S. P., Salnikov A. V. The Late Jurchen (Early Manchu) Helmet of the Second Half of the 1610 s to the Mid-1630s from the Collection of the Armoury Chamber of the Moscow Kremlin [Поздний чжурчжэньский (ранний маньчжурский) шлем второй половины 10-X - середины 30-х гг. XVII в. из собрания Оружейной палаты Московского Кремля] // Былые годы. 2017. Т. 46. № 4. С. 1140-1173.

Bobrov, Kushkumbayev, Salnikov 2018 Bobrov L. A., Kushkumbayev A. K., Salnikov $A$. $V$. Oirat Helmet of the XVII - mid-XVIII centuries from the Akmola Regional History Museum [Ойратский шлем XVII - середины XVIII вв. из

\section{References}

Akhmetzhan K. S. Ethnography of Traditional Kazakh Weaponry. Almaty: Almatykitap, 2007. 216 p. (In Russ.)

Anisimova M. A. Military-Historical Museum of Artillery, Engineer and Signal Corps: Weapons of the East, $15^{\text {th }}-$ Mid-20 $0^{\text {th }}$ Centuries. St. Petersburg: Atlant, 2013. 527 p. (In Russ.)

Astakhov A. Yu. (comp.) Body Armor, Weapons, Carriages, and Horse Tack. Drawings of F. Solntsev. St. Petersburg: Belyi Gorod, 2015. 146 p. (In Russ.)

Beer R. The Handbook of Tibetan Buddhist Symbols. Moscow: Orientaliya, 2013. 336 p. (In Russ.)

Bobrov L. A. 'A flock of crows' over the Crimea. Tatar and Kalmyk confrontation in the northern Black Sea steppes (September 1661 - January 1663). Medieval Turkic-Tatar States. 2014. Vol. 6. Pp. 239-249. (In Russ.)

Bobrov L. A. 'The Tatar' helmet with combined camail (protection of a neck and a throat) from
Акмолинского областного историко-краеведческого музея] // Былые годы. 2018. T. 48. № 2. C. 443-455.

Bobrov, Obraztsov, Salnikov 2019 - Bobrov L., Obraztsov V., Salnikov A. Oirat helmet of the XVII - mid-XVIII centuries from the State Hermitage Museum [Ойратский шлем второй половины XVII- середины XVIII вв. из Государственного Эрмитажа] // Былые годы. 2019. Т. 51. № 1. С. 5-19.

Gorelik 1979 - Gorelik M. Oriental armour of the Near and Middle East from the eighth to the fifteenth centuries as shown in works of art. In: Elgood R. (ed.). Islamic Arms and Armour. L., 1979. P. 38-63.

LaRocca 1999 - LaRocca D. J. An approach to the study of arms and armour from Tibet // Royal Armouries Yearbook. 1999. Vol. 4. P. 113132.

LaRocca 2006 - LaRocca D. J. Warriors of the Himalayas. Rediscovering the Arms and Armor of Tibet. New York: The Metropolitan Museum of Art; New Haven; London: Yale University Press, 2006. 307 p.

Martyushov, Shirin 2018 - Martyushov R. A., Shirin $Y . V$. Difficulties Interpreting of Written and Archaeological Sources of Information of Ferrous Metallurgy of the Kuznetsk Tatars // Былые годы. 2018. № 49. Вып. 3. С. 915-930.

the Tobolsk State Historical-Architectural Museum-Reserve. Novosibirsk State University Bulletin. Series: History and Philology. 2009. Vol. 8. No. 3. Pp. 251-254. (In Russ.)

Bobrov L. A., Khudyakov Yu. S. Nomads of Central Asia and Southern Siberia in the Late Medieval and Modern Ages (15 $5^{\text {th }}-$ Mid$18^{\text {th }}$ Centuries): Weaponry and Tactics. St. Petersburg: St. Petersburg University, 2008. 770 p. (In Russ.)

Bobrov L. A., Khudyakov Yu. S. Nomads of Mongolia and Kalmykia: military headgears, mid- $16^{\text {th }}$ - early $18^{\text {th }}$ centuries. In: Soyonov V. I. (ed.) Antiquities of the Altai. Vol. 11. GornoAltaysk: Gorno-Altaysk State University; Surazakov Institute for Altaic Studies, 2003. Pp. 138-155. (In Russ.)

Bobrov L. A., Kushkumbayev A. K., Salnikov A. V. Oirat helmet of the XVII - mid-XVIII centuries from the Akmola Regional History Museum. Bylye Gody. 2018. Vol. 48. No 2. Pp. 443-455. (In Eng.) 
Bobrov L. A., Orlenko S. P. 'Kalmyk Caps' of the Kremlin Armoury. Oriental Studies. 2020. No. 2. Pp. 278-304. (In Russ.)

Bobrov L. A., Orlenko S. P. A late $16^{\text {th }}$ to early $17^{\text {th }}$ century Mongolian ceremonial helmet from the Moscow Kremlin Armoury. Archaeology, Ethnography and Anthropology of Eurasia. 2017. No. 4. Pp. 127-135. (In Russ.)

Bobrov L. A., Ozheredov Yu. I. Late medieval 'robe'-type body armor of a Buddhist warrior. In: Ozheredov Yu. I. (ed.) Ancient, Medieval and Modern North and Central Asia: Materials and Studies. Tomsk: Tomsk State University, 2010. Vol. III. Is. 1. Pp. 7-64. (In Russ.)

Bobrov L. A., Ryumshin M. A. '... And against them, they could not withstand anywhere and they are not able to fight against them'. Arms and military tactical aspect of the KalmykNogai and Kalmyk-Tatar wars during the first half - middle of the $17^{\text {th }}$ century. Golden Horde Civilization. 2015. Vol. 8. Pp. 357-378. (In Russ.)

Bobrov L. A., Zaytsev V. P., Orlenko S. P. Central Asian 'bulat helmet' of the end of the $16^{\text {th }}-$ the first third of the $17^{\text {th }}$ century from among the gifts of Erdeni Dai mergen Nangso. Archaeology of the Eurasian Steppes. 2017. No. 5. Pp. 216-230. (In Russ.)

Bobrov L. A., Zaytsev V. P., Orlenko S. P., Salnikov A. V. The late Jurchen (early Manchu) helmet of the second half of the 1610s to the mid-1630s from the collection of the Armoury Chamber of the Moscow Kremlin. Bylye Gody. 2017. Vol. 46. No. 4. Pp. 1140-1173. (In Eng.)

Bobrov L., Obraztsov V., Salnikov A. Oirat helmet of the XVII - mid-XVIII centuries from the State Hermitage Museum. Bylye Gody. 2019. Vol. 51. No. 1. Pp. 5-19. (In Eng.)

Boeheim W. An Encyclopedia of Weapons. St. Petersburg: Orkestr, 1995. 576 p. (In Russ.)

Elikhina Yu. I. (ed.) The Shrines of Mercy: Tibetan Buddhist Art. Exhibition Catalogue. St. Petersburg: State Hermitage Museum, 2015. 512 p. (In Russ.)

Gorelik M. Oriental armour of the Near and Middle East from the eighth to the fifteenth centuries as shown in works of art. In: Elgood R. (ed.) Islamic Arms and Armour. London, 1979. Pp. 38-41. (In Eng.)

Gorelik M. V. Armies of $10^{\text {th }}-14^{\text {th }}$ Century Mongols (Tatars): Art of War, Ammunition, Weaponry. Moscow: Vostochnyi Gorizont, 2002. 84 p. (In Russ.)
Gorelik M. V. Early Mongolian body armor: $9^{\text {th }}$ - mid-14 $4^{\text {th }}$ centuries. In: Derevyanko A. P., Natsagdorj Sh. (eds.) Archaeology, Ethnography, and Anthropology of Mongolia. Novosibirsk: Nauka, 1987. Pp. 163- 208. (In Russ.)

Gorelik M. V. Medieval Mongolian body armor. In: The Third International Congress of Mongolists. Proceedings. Ulaanbaatar, 1979. Pp. 76-97. (In Russ.)

Gorelik M. V. Mongol (Tatar) defensive weapons: mid- $14^{\text {th }}-$ early $15^{\text {th }}$ centuries. In: Rybakov B. A. (ed.) The Battle of Kulikovo in Our National History and Culture. Moscow: Moscow State University, 1983. Pp. 244-269. (In Russ.)

Khizhnyak O. S. The Stupa: Beginnings of the Shaping of a Buddhist Cult. St. Petersburg: St. Petersburg University, 2008. 272 p. (In Russ.)

Khudyakov Yu. S., Bobrov L. A., Filippovich Yu. A. Body armor of late medieval Central Asian warriors: experimental reconstruction and functional analysis. Novosibirsk State University Bulletin. Series: History and Philology. 2005. Vol. 4. No. 5. Pp. 95-103. (In Russ.)

Kravtsova M. E. World Artistic Culture: A History of China's Arts. St. Petersburg: Lan, TPIADA, 2004. 960 p. (In Russ.)

LaRocca D. J. An approach to the study of arms and armour from Tibet. Royal Armouries Yearbook. 1999. Vol. 4. Pp. 113-132. (In Eng.)

LaRocca D. J. Warriors of the Himalayas. Rediscovering the Arms and Armor of Tibet. New York: The Metropolitan Museum of Art; New Haven; London: Yale University Press, 2006. 307 p. (In Eng.)

Lenz E. Count S. Sheremetev's Collection of Weapons: Inventory Catalogue. St. Petersburg, 1895. 223 p. (In Russ.)

Martyushov R. A., Shirin Y. V. Difficulties interpreting of written and archaeological sources of information of ferrous metallurgy of the Kuznetsk Tatars. Bylye Gody. 2018. Vol. 49. No. 3. Pp. 915- 930. (In Eng.)

Samigulov G. Kh. The Seydyashevs and Kulmametevs - reconstruction attempts. In: Russia's Annexation of Siberia. New Data. Tyumen: Tyumen State University, 2014. Pp. 162-166. (In Russ.)

Samigulov G. Kh., Tychinskikh Z. A. New sources on the history of Murzas Kulmametev. Vestnik Arheologii, Antropologii i Etnografii. 2018. No. 1 (40). Pp. 99-107. (In Russ.)

Shindler O. V. On the question of the legitimacy of using the term 'shishak' in the $16^{\text {th }}$ cen- 
tury, its origin and the debunking of one outdated myth. History of Military Affairs: Research and Sources. Posted on September 24, 2018. Vol. X. Pp. 163-187. Available at: http://www.milhist.info/2018/09/24/schindler_6 (accessed: February 16, 2020). (In Russ.)

Shindler O. V. Russian helmets of the $16^{\text {th }}$ century. History of Military Affairs: Research and Sources. Posted on May 10, 2016. Vol. VIII. Pp. 167-219. Available at: http://www.milhist. info/2016/05/10/schindler_3 (accessed: May 10, 2016). (In Russ.)
Veltman A. F. The Kremlin Armoury (Moscow). $2^{\text {nd }}$ ed., rev. Moscow: Bakhmetev, 1860. 288 p. (In Russ.)

Veltman A. F. The Kremlin Armoury (Moscow). Moscow: I. Stepanov, 1844. 172, 74, VIII p., 33 p. (In Russ.)

Vodyasov E. V. Kondoma Tatars and the bloomery process (source: the Great Northern Expedition). Bylye Gody. 2016. Vol. 40. No. 2. Pp. 335-344. (In Eng.)

Zlatkin I. Ya. History of the Dzungar Khanate: 1635-1758. Moscow: Nauka, 1983. 332 p. (In Russ.) 